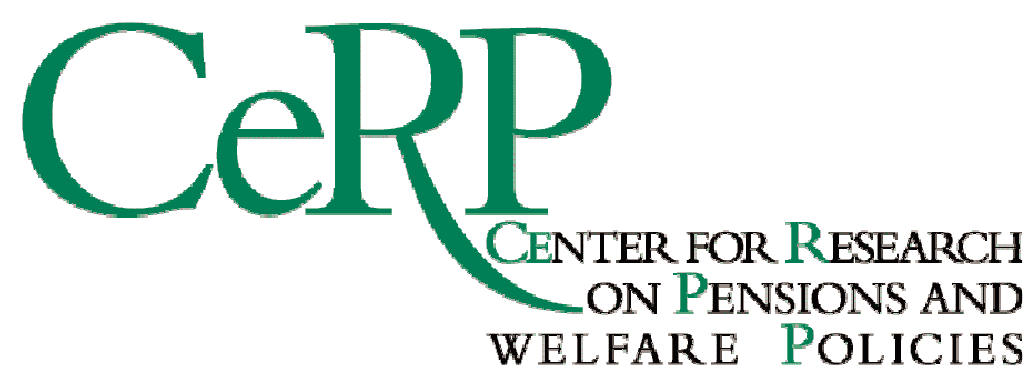

Working Paper 121/11

\title{
THE EFFECT OF FINANCIAL LITERACY ON MORTAGE CHOICES
}

Elsa Fornero

Chiara Monticone

Serena Trucchi 


\title{
The effect of financial literacy on mortgage choices
}

\author{
Elsa Fornero* Chiara Monticone $^{\dagger} \quad$ Serena Trucchi ${ }^{\ddagger}$
}

September 29, 2011

\begin{abstract}
A growing body of literature shows that financial literacy affects household savings and investment choices. Less attention has, however, been devoted to its effect on debt behaviour. This paper contributes to filling this gap by considering how financial literacy influences household attitudes with respect to the most common of family debts, the house mortgage. Using Italy as a case study, it considers the effect of financial literacy on three mortgage-related decisions, namely, the choice of lender and the decision between adjustable and fixed interest rates, as well as situations of mortgage misconduct. We find that the more financially literate individuals are, i) the more likely they are to shop around and compare mortgages for better economic conditions (in contrast to the less financially literate, who tend to take on mortgages from the first financial intermediary they contact), ii) the more prepared they are to diversify risks by better connecting their risk exposure with different types of mortgage, and iii) the less likely they are to experience delays in repayments.
\end{abstract}

\section{Introduction}

Several reasons explain why the issue of financial (il)literacy has recently gained prominence in both academic research and policy analysis. Pension reforms in the US and in most European countries have greatly increased individuals' responsibility in the formation and management of resources

\footnotetext{
*University of Turin, CeRP-Collegio Carlo Alberto and Netspar; elsa.fornero@unito.it.

${ }^{\dagger}$ OECD, CeRP-Collegio Carlo Alberto, Netspar. The research for this paper was carried out when Chiara Monticone was at CeRP-CCA and is not part of her work at the OECD; corresponding author: monticone@cerp.unito.it.

${ }^{\ddagger}$ University of Eastern Piedmont and CeRP-Collegio Carlo Alberto; trucchi@cerp.unito.it.
} 
for retirement, thus increasing the scope for better information and basic financial knowledge. Reduced dependence on rather rigid public pension schemes - where individuals have little, if any, choice - particularly characterizes middle-aged and young generations, who have to rely on privately managed pension plans to achieve adequate income after retirement. In parallel, the complexity of financial instruments has greatly increased and individuals have to deal with new and more sophisticated financial products. Finally, profound changes in family structure have also contributed to the 'individualization' of responsibilities, granting women new opportunities but also exposing them to new risks.

These structural changes have raised concerns about whether individuals possess at least the basic financial knowledge needed to make good savings and investment decisions. A recent body of literature investigates the issue both across and within countries (Atkinson et al., 2006; Lusardi and Mitchell, 2011; Monticone, 2010; Jappelli, 2010; van Rooij et al., 2011). This literature shows i) widespread financial illiteracy in several countries, including the US, and ii) a strong association of financial literacy with sounder financial behaviour. Even though the direction of the relation between financial literacy and financial behaviour deserves further investigation, the literature shows that knowledge of relatively simple concepts such as compound interest rates, the difference between real and nominal values, and the notion of risk diversification is tied to more efficient financial behaviour, such as planning and saving for retirement (Bucher-Koenen and Lusardi, 2011; Fornero and Monticone, 2011; Lusardi and Mitchell, 2007; van Rooij et al., 2008) and stock market participation and portfolio diversification (van Rooij et al., 2011; Kimball and Shumway, 2007; Guiso and Jappelli, 2008). Moreover, a higher degree of financial literacy predicts greater sensitivity to financial incentives and costs, such as fees in mutual funds and pension plans (Hastings and Tejeda-Ashton, 2008; Nöth and Puhan, 2009).

Concern for financial illiteracy is thus shared by scholars and policy makers alike, and various institutions argue in favour of educational programmes both for adults and in schools. In 2008 the Organisation for Economic Co-operation and Development launched the International Network on Financial Education to promote and facilitate international cooperation between policy makers and other stakeholders on financial education issues worldwide. In Italy, various initiatives have been launched to pilot financial education programmes, for example, by the Ministry of Education and the Bank of Italy.

Somewhat surprisingly, little attention has been devoted to assess the impact of financial literacy on households dealing with mortgages, which typi- 
cally are the most important liability in a family financial account (Campbell and Cocco, 2003). Financial literacy, however, influences attitudes towards debt in general and mortgages in particular. Lusardi and Tufano (2009) find a significant association between debt literacy - as measured by three questions about interest applied to debt in general, credit cards, and the time value of money - and self-assessed over-indebtedness for the US population. Using panel data from the US Health and Retirement Study (19982006), Duca and Kumar (2010) analyze mortgage equity withdrawals. Their findings indicate that, controlling for several covariates, financially illiterate households are significantly more likely to withdraw housing equity. Evidence from the US also shows that many households are not aware of their mortgages characteristics. Bucks and Pence (2008) use borrower/lender reports to examine whether mortgage borrowers know their contract terms. The authors find that borrowers with adjustable rate mortgages (ARMs) are not aware of various aspects of their contract terms and tend to underestimate how much their interest rate can increase in one shot and over a lifetime. Gerardi et al. (2010) investigate the effects of a particular aspect of borrowers' financial literacy - numerical ability - on defaults and foreclosures in the US subprime mortgage market. The authors find a significant negative correlation between numerical ability and various measures of mortgage delinquency. Their result is robust with respect to sociodemographic control variables and to the characteristics of mortgage contracts.

This paper contributes to the above literature by examining the role of financial literacy on three mortgage-related decisions: i) the choice of a provider, ii) the choice of the specific type of contract (adjustable rate versus nominal fixed rate mortgages, ARM/FRM), and iii) the fulfilment of required payments. Given the complexity of decisions about housing and mortgages, we do not base our analysis on a structural model but, rather, rely on a reduced-form approach to investigate the role of financial literacy, controlling for relevant economic and sociodemographic factors. Furthermore, due to data constraints, instead of using a unified framework, allowing us to also study the interactions between the various decisions, we are forced to adopt a piecemeal approach. We believe, however, that our results yield some interesting results.

When asking for a mortgage, the first decision concerns the provider. Mortgage contracts differ with respect to many important dimensions, and we are interested in testing whether consumers compare different intermediaries before choosing one and whether they choose according to the criterion of 'best economic conditions'. Our results show that economic conditions are more relevant for more financially literate individuals, while the less literate 
are more likely to take on a mortgage from the first financial intermediary contacted.

The choice of the type of contract exposes the borrower to different financial risks (Campbell and Cocco, 2003). Our a priori belief is that more literate individuals should weigh how mortgage characteristics expose them to different risks, considering their particular earning risks. Within this framework, we focus on the choice between ARMs and FRMs. Our results support the hypothesis that financial literacy improves households' ability to correctly evaluate their risk exposure, allowing them to limit potential welfare losses.

Finally, the inability to regularly meet mortgage obligations is a key indicator of over-indebtedness. This can be due to unexpected events (e.g., job loss or health shock), but can also be the result of inappropriate choices made when taking out the mortgage. Badly choosing the mortgage lender or selecting an inappropriate type of contract given one's own background risk makes it more difficult to meet mortgage obligations. Since financially illiterate individuals may be less aware of the risks implied by their mortgage conditions (Bucks and Pence, 2008), they may choose an unsuitable contract and thus be more susceptible to mortgage delinquency (Gerardi et al., 2010). Our estimates indicate that financially literate individuals are less likely to experience delays in repayments.

The empirical analysis is based on Italian data. The rationale for this choice is twofold. First, the Bank of Italy's Survey on Household Income and Wealth (SHIW) constitutes a rich data source to investigate mortgage behaviour, since it contains, in addition to detailed sociodemographic variables, detailed information on both mortgage features and financial literacy. Second, the Italian mortgage market experienced a fast increase in recent years, marking the transition from the family-based financing of house purchase to a more market-oriented one (Casolaro et al., 2006). Our results shed further light on the relevance of financial literacy to household savings/investment decisions, such as the choice of a mortgage provider and the (proper or poor) evaluation of risk exposure, including the risk of overindebtedness and the subsequent inability to face obligations. From a policy perspective, these results stress the importance of actions aimed at increasing households' financial literacy as an effective instrument to improve their decision making and, ultimately, their welfare.

The paper is structured as follows. Section 2 describes the dataset used and our measure of financial literacy. Section 3 analyzes the choice of mortgage lender. Section 4 examines the choice of the type of mortgage contract (ARM versus FRM), while Section 5 investigates the effect of financial 
literacy on the probability of late mortgage payments. Finally, Section 6 concludes the paper.

\section{The data}

Our dataset consists of the 2006 and 2008 waves of the SHIW. The survey covers a representative sample of the Italian resident population, around 8000 households - defined as a group of individuals related by blood, marriage, or adoption and sharing the same dwelling - and contains detailed information on household sociodemographic characteristics, consumption, income, and wealth. The household heads (i.e., the person responsible for the household budget) were the respondents. Since 2006, financial literacy questions have been included in all SHIW waves (although not the same as in the 2006 and 2008 waves). Our analysis uses the following questions.

1. Understanding a bank account statement. Suppose you receive this account statement from your bank. Can you tell me what sum of money is available at the end of May (see Figure 1)? Amount in euro (correct answer 279 euro)/Do not know

2. Understanding inflation. Imagine leaving 1,000 euro in a current account that pays $1 \%$ interest and has no charges. Imagine also that inflation is running at $2 \%$. Do you think that if you withdraw the money in a year's time you will be able to buy the same amount of goods as if you spent the 1,000 euro today? Yes/No, I will be able to buy less (correct answer)/No, I will be able to buy more/Do not know

3. Understanding mortgages. Which of the following types of mortgage do you think will allow you from the very start to fix the maximum amount and number of instalments to be paid before the debt is extinguished? Adjustable rate mortgage/ Fixed rate mortgage (correct answer)/Adjustable rate mortgage with fixed instalments/Do not know

4. Understanding risk diversification. Which of the following investment strategies do you think entails the greatest risk of losing your capital? Investing in the shares of a single company (correct answer)/Investing in the shares of more than one company/Do not know

5. Understanding risky assets. A company can be financed by issuing either shares (equity securities) or bonds (debt securities). Which 
do you think is most risky for the investor? Shares (correct answer)/Bonds/They are equally risky/I don't know the difference between shares and bonds/Do not know

The 2006 SHIW includes questions 1 to 3 (and others not reported), while the 2008 SHIW contains all of the above questions. These are based on similar questions that have been developed in the literature and have been widely used to measure financial knowledge. In particular, the questions about inflation, interest, and risk diversification are similar to those of the 2004 Health and Retirement Study (Lusardi and Mitchell, 2006), while the ones on mortgages and bank account statements are derived from those used by Atkinson et al. (2006) to investigate financial capability in the UK. Considering the entire 2006 sample, half correctly answered the questions about understanding a bank account statement ( $43 \%$ did not know), almost $60 \%$ gave the correct answer to the question about inflation $(30 \%$ did not know), and $47 \%$ correctly answered the question on mortgages (34\% did not know). In 2008, the share of correct answers for the first risk question was $45 \%$ (28\% did not know) and that for the second was 34\% (19\% did not know). More details on the distribution of financial literacy in Italy can be found in Monticone (2010) and Fornero and Monticone (2011).

This paper focuses on financial literacy as financial knowledge. This is consistent with an authoritative definition of financial literacy, that is, 'the ability to use knowledge and skills to manage financial resources effectively for a lifetime of financial wellbeing' (President's Advisory Council on Financial Literacy, 2008), and with most of the existing empirical literature (see Hung et al. (2009), for a review of financial literacy definitions and measurement).

As already said, to examine the three mortgage aspects in which we are interested, we have to rely on three different samples, which are described in each section below. The measure of financial literacy used in each part of the analysis will thus vary according to the questions posed.

\section{Choosing a mortgage lender}

When choosing a financial product, shopping around and comparing offers is very important. However, according to financial capability surveys in both the US and the UK, not many consumers seem to do so (FINRA Investor Education Foundation, 2009; Atkinson et al., 2006). For example, only onethird of American citizens collected information about different credit cards from various companies, while half compared offers from different lenders for 
their most recent auto loan. Results for mortgages are more encouraging, with two-thirds comparing offers from different lenders or brokers before getting their mortgage (FINRA Investor Education Foundation, 2009). The UK survey agrees that people are generally not very good at choosing financial products, since they tend to renew existing products without considering alternatives and do not shop around when purchasing new ones (Atkinson et al., 2006). On the other hand, it also appears that more financially literate individuals, being better equipped to choose between financial products, tend to select them on the basis of economic conditions, such as costs, rather than branding.

Direct research on the effects of financial education on mortgages, however, is scarce. A field experiment on Mexican workers - where respondents had to choose between several investment funds for their retirement plans based on information about fees and past returns - provides evidence that respondents scoring higher in financial literacy are more price sensitive when ranking investment funds (Hastings and Tejeda-Ashton, 2008). It also shows that illiterate workers pay more attention to fees when these are presented in absolute value (pesos) rather than as a percentage, while the financially literate do not change their behaviour when fees are presented either way. Finally, the study shows that all respondents - but especially the financially illiterate - place a lower weight on fees when returns are included in the information presented. Nöth and Puhan (2009) investigate the impact of financial literacy on the ability to minimize mutual funds' fees. An on-line survey of more than 3,000 readers of a large German weekly magazine for private investors (Borse Online) asked respondents to choose between three index funds with the same benchmark but different fund inception dates and fee structures. Even though the sample had a positive selection bias, more than $94 \%$ of the participants failed to minimize fees. The authors identify financial literacy as one of the variables explaining the ability to make feeminimizing choices. Clearly, the choice of mortgage lender is likely to be also driven by other factors we are unable to observe, such as trust in one particular financial institution.

\subsection{Empirical strategy}

The 2008 SHIW allows one to study how households choose their mortgage providers. To study whether financial literacy affects this choice, we use the following question.

Consider all loans and mortgages for the home or for other proper- 
ties owned by the household (if there is more than one loan for the same item, consider the largest). Why did you choose the institution providing the loan (only one answer)? 1. It offered better financial conditions than competitors./ 2. It offered better non-financial conditions than competitors (e.g., rapid processing)./ 3. It was the only one to grant the loan./ 4 . It was the first institution I contacted.

We consider only households who had outstanding debt at the time of the interview and who took out their mortgage in one of the two years the survey refers to, that is, 2007 and $2008(N=148)$. We restrict the sample to recent mortgages to control for sociodemographic characteristics at the time the choice was made. We estimate the following multinomial logit model:

$$
P(y=j \mid \mathbf{X})=\frac{\exp \left(\mathbf{X} \boldsymbol{\beta}_{j}\right)}{1+\sum_{h=1}^{J} \exp \left(\mathbf{X} \boldsymbol{\beta}_{h}\right)} \quad j=1, \ldots, J
$$

where $J=4$ and the dependent variable is the probability of choosing one of the four alternatives outlined above. Summary statistics for the estimation sample are shown in Table 1 (Panel A). About $61 \%$ of the sample chose the first alternative (i.e., the intermediary offering the best financial conditions) and $23 \%$ chose the fourth alternative (i.e., the first intermediary contacted); $10 \%$ chose better non-financial conditions and $5 \%$ took out their mortgage from the only institution granting them a loan. The measure of financial literacy used in this part of the analysis is based on four questions (bank statement, inflation, risk diversification, and risky assets) and is calculated through two alternative means: a dummy variable taking the value of one if the respondent gives four correct answers, and zero otherwise, and the number of correct answers (from zero to four). Within the estimation sample, about one-third gave four correct answers, while the average number of correct answers was 2.5 out of $4 .^{1}$

The other explanatory variables - included in vector $\mathbf{X}$ in equation (1) - are gender (a dummy taking the value of one for male respondents, and zero otherwise), age, the number of income earners in the household, the number of household members, education (the respondent's years of schooling), dummies indicating the macro region of residence, a dummy indicating whether the household head is unemployed, total household income, and a dummy taking the value of one if the household has positive liquid wealth,

\footnotetext{
${ }^{1}$ It should be noted that households who have taken out a mortgage tend to display higher financial literacy than households who have not, as highlighted in Fornero and Monticone (2011). However, this does not affect our analysis, since we focus exclusively on subsamples of mortgage holders.
} 
and zero otherwise. We include proxies for household economic conditions (e.g., the household head being unemployed, household income, and wealth), since they are likely to be related to liquidity constraints driving the choice of the third alternative (i.e., only one institution granting the loan).

\subsection{Results}

Tables 2 and 3 report the marginal effects on the probability of choosing each alternative. In Table 2, the measure of financial literacy is a dummy variable taking the value of one if the respondent gives all four correct answers, and zero otherwise, while Table 3 uses the number of correct answers. Gender, age, household composition, and education have no significant effect. Living in the northeast of the country increases the probability of choosing better economic conditions and reduces that of not shopping around. Being unemployed increases the probability of choosing the first intermediary contacted and decreases the probability of choosing any other alternative. This may be due to the fact that, anticipating difficulties in obtaining a mortgage, respondents directly ask the provider that is most likely to grant them a loan. Household wealth has no effect, while household income increases the probability of choosing better non-financial conditions (such as more rapid processing). These findings are consistent with high-income individuals having a higher opportunity cost of time, leading them to prefer a faster procedure to a (potentially) lower cost.

Financial literacy increases the probability of choosing better economic conditions (first alternative) and at the same time decreases that of not comparing options (i.e., choosing the first lender contacted, the fourth alternative). This is consistent with our hypothesis that financial literacy enables consumers to select financial products according to the relevant aspects. While the results for most covariates are very similar across Tables 2 and 3, financial literacy is not significant in Table 3.

\section{Type of mortgage}

The recent financial crisis has demonstrated, even dramatically, that mortgage obligations can have a severe impact on household finances, possibly driven by the scarce awareness of the risks the loan involves. Even though contracts are quite complex and differ along many dimensions, conventional mortgages can be broadly classified into two main categories: ARM and FRM, which expose households to different financial risks. FRM and ARM are the main alternatives available to Italian homeowners. Rossi (2008) 
shows that mortgages supplied in the Italian market are mainly traditional ones; newer products, such as mortgages with constant payments and flexible duration, are rare.

Campbell and Cocco (2003) conduct a normative analysis of the choice of a mortgage contract, providing a neat theoretical framework of how personal characteristics should lead the household to prefer one form of mortgage over another. The authors highlight the different risks affecting different types of contracts. A nominal FRM, without a prepayment option, ${ }^{2}$ is affected by wealth risk, that is, the risk of a fall in nominal interest rates/inflation, making the mortgage too expensive with respect to current market conditions.

Conversely, an ARM is affected by income risk, that is, the risk of shortterm variability in the real monthly payments occurring if expected inflation and nominal interest rates increase. Importantly, this short-term variability matters if the homeowner faces binding borrowing constraints. ${ }^{3}$ In line with this view, the choice of the type of mortgage is, first of all, a problem of risk understanding, where exposure is conditional on market features as well as on individual characteristics (e.g., earning risk) that make a specific contract more or less suited to a household.

According to this framework, households with large houses relative to their income, volatile labour income, ${ }^{4}$ and high risk aversion are particularly adversely affected by the income risk of an ARM, and should therefore be more likely to choose an FRM. Moreover, if a household is currently borrowing constrained, the most appropriate mortgage is more likely to be that with the lowest current interest rate. ${ }^{5}$ Thus, the model implies that homeowners should respond to the yield spread between FRM and ARM rates, which is driven by the yield spread between long- and short-term bond yields.

\footnotetext{
${ }^{2} \mathrm{~A}$ prepayment option (i.e., the possibility of calling the mortgage at face value when nominal interest rates fall, taking out a new mortgage contract at a lower interest rate) protects the homeowner against the wealth risk. It is, however, costly and raises the interest rate charged on the FRM.

${ }^{3}$ Constraints bind in states of the world with low income and low house prices; in these states buffer-stock savings are exhausted, and home equity falls below the minimum required to take out a second loan. The danger of an ARM is that it will require higher interest payments in this situation, forcing a temporary but unpleasant reduction in consumption.

${ }^{4}$ Where income volatility is uncorrelated or negatively correlated with volatility in inflation.

${ }^{5}$ Unconditionally, this is typically the ARM, since the FRM rate incorporates a positive term premium and the cost of the FRM prepayment option. However, if the short-term interest rate is currently high and likely to fall, the FRM can have a lower rate.
} 
Previous papers have examined the determinants of the choice between ARMs and FRMs, but to our knowledge no attempt has been made to assess the impact of financial literacy on this choice. For the US, Dhillon et al. (1987) finds that borrowers' characteristics are not statistically significant, while the probability of choosing an ARM is affected by the relevant interest rates. Brueckner and Follain (1988) find that the fixed-adjustable rates differential is significant in the choice of an ARM, and that more mobile and higher-income households are more likely to choose an ARM.

As for Italy, a recent paper by Paiella and Pozzolo (2007), based on the 1995-2004 waves of the SHIW, somewhat downgrades the role played by borrowers' characteristics (employment status, income, and mobility have no effect), while stressing the greater responsibility of both price variables and the amount of the initial payment. More specifically, and consistent with the hypothesis that borrowers expect some mean reversions in market interest rates, the authors find that the probability of choosing an ARM increases with both the rate on ARMs and the spread between fixed and adjustable rates. House prices per square meter also have a positive effect, consistent with the idea that ARMs are preferred for their lower initial payment. This section investigates the effects of financial literacy on the choice between ARMs and FRMs. Our hypothesis is that more literate individuals should be able to better understand the risks of the two different contracts and the correlations with their own personal characteristics. Consequently, we expect the impact of variables capturing household exposure to income and wealth risks to be larger for more literate individuals.

\subsection{Empirical strategy}

The empirical analysis relies on both the 2006 and 2008 waves of the SHIW. To control for household characteristics at the time the mortgage was signed, the sample includes only households who bought their dwelling in the two years the surveys refer to, that is, 2005-2006 and 2007-2008 $(N=170)$.

To address the issue, we estimate a probit model for the decision between ARMs and FRMs, investigating the importance of individual and market features and analyzing whether the effects of the explanatory variables are different for more financially literate households:

$$
P(y=1 \mid \mathbf{X})=\Phi\left(\mathbf{X} \boldsymbol{\beta}_{j}\right)
$$

where $\mathrm{y}=1$ when the household chose an FRM and $\Phi(\cdot)$ is the normal cumulative distribution function. Summary statistics of these variables for the estimation sample are shown in Table 1 (Panel B). Slightly more than 
half of the sample has an FRM. The measure of financial literacy is based on the three questions that appear in both waves (i.e., understanding a bank statement, inflation, and mortgages). As before, financial literacy is measured in two ways: through a dummy variable taking the value of one if the respondent gives three correct answers, and zero otherwise, and the number of correct answers (from zero to three). About $40 \%$ correctly answered all three questions, and respondents gave, on average, 1.7 correct answers out of three.

Other explanatory variables (in vector $\mathbf{X}$ in equation (2)) include gender (a dummy for male respondents), age, the number of income earners in the household, the number of household members, the education of the household head (years of schooling), and a series of dummies indicating selfemployment, the macro region of residence, whether the household head is very risk averse, the ratio between the total value of the mortgage and total household income, the household's liquid wealth, the interest rate spread, and per capita real gross domestic product (GDP) growth in the year when the mortgage was obtained.

We expect risk-averse households to prefer FRMs when they are likely to suffer from liquidity constraints, because the short-term variability of payments is more harmful to them (for non-liquidity-constrained households, a clear expectation is not possible, since both types of mortgages entail risks). The effects of the mortgage-to-income ratio are also ambiguous a priori: On the one hand, a higher ratio of mortgage to household income increases the attractiveness of ARMs due to lower current mortgage payments; on the other hand, a higher ratio boosts the exposure to income risk, enhancing the attractiveness of FRMs. Wealthier households, as well as households with more income earners for a given number of $\mathrm{m}$ embers, should be more prepared to buffer against the income risk of ARMs. We also control for the GDP per capita growth rate to control for the business cycle phase when the mortgage was taken out. ${ }^{6}$

To analyse the sensitivity of the choice between ARMs and FRMs to market features, we include as an explanatory variable the spread between the 20-year Euro Interest Rate Swap (Eurirs) interest rate and the threemonth Euribor rate that captures the reference interest rates for, respectively, FRMs and ARMs. Descriptive statistics of the interest rates, their difference, and the real per capita GDP are shown in Table 4. The time series of both rates during 2001-2010 are displayed in Figure 2. Both the

\footnotetext{
${ }^{6}$ Since the GDP growth rate refers to the year the mortgage was taken out, we cluster standard errors by year.
} 
Eurirs and Euribor interest rates increase until mid-2008, with their difference decreasing over time; afterwards the Euribor drops abruptly while the Eurirs declines more slowly.

The effect of the spread between long- and short-term interest rates is not straightforward. On one hand, it is driven by expectations about the yield curve: the more interest rates are expected to grow, the larger is the spread, which makes the spread positively correlated with future interest rate increases and income risk. Consequently, the higher the spread, the less attractive an ARM should be. On the other hand, the spread captures the relative cost, in terms of current mortgage payments, of an FRM with respect to an ARM. Thus, liquidity-constrained households should be more interested in an ARM when the interest rate spread is higher.

Since we are interested in whether higher financial literacy allows households to better choose a type of mortgage, given their background risk characteristics, we interact financial literacy with the number of income earners in the household, a dummy indicating whether the household head is selfemployed, the mortgage-to-income ratio, and the interest rate spread.

\subsection{Results}

Table 5 reports the results of the probit model estimation. In particular, it shows the marginal effects on the probability of choosing an FRM (without interaction terms). In addition to presenting results for all levels of financial wealth, we also split the sample below and above the median household financial wealth to isolate households that are more likely to be liquidity constrained and thus more sensitive to income risk due to the short-term variability of monthly real payments. While columns I and IV of Table 5 report the effects for all wealth levels, columns II and V (III and VI) refer to households with wealth below (above) the median. ${ }^{7}$ A word of caution on the robustness of our results is, however, due, since this part of the analysis - which tries to capture the effect of risk awareness on a very complex household decision - relies on a rather small number of observations. A few interesting indications emerge, however. First, in line with Dhillon et al. (1987) and Paiella and Pozzolo (2007), individual borrower characteristics seem to have little influence on the mortgage decision. One exception is financial wealth, which proxies for household ability to face the income risk associated with an ARM contract. Hence, our results suggest that richer households are less worried by income risk and are therefore more likely to

\footnotetext{
${ }^{7}$ The median value of financial wealth is 6,308 euros (in 2008 prices).
} 
have an ARM (even though the effect is significant only in columns II and VI). Second, households living in the north are more likely to prefer ARMs, and the effect is even stronger for liquidity-constrained households. Again, this is consistent with higher wealth levels in northern regions. Third, and consistent with the possibility that many households are simply unaware of their risk exposure (as suggested by Valletta and Zocchi, 2007), we do not find any relation between risk aversion and mortgage choice.

Further results show that a higher ratio of the mortgage value to household income is significantly associated with a preference for an FRM, presumably because of the higher exposure to income risk implied by higher mortgage-to-income ratios. A higher interest rate spread predicts a lower probability of an FRM, consistent with the fact that the spread captures the relative cost of an FRM with respect to an ARM, making initial ARM payments lower than FRM ones in the presence of a positively sloped yield curve. Finally, individuals with higher financial literacy (both measures) are more likely to choose an FRM. This can be interpreted as the effect of the greater awareness of more financially knowledgeable households of the income risk embedded in ARMs, and of the fact that interest rates were relatively low.

To examine the channels through which financial literacy drives the choice between ARMs and FRMs, we allow the effect of some of the main explanatory variables to depend on financial literacy. Thus, in Table 6, we add interaction terms between financial literacy and risk-related factors, such as the number of income earners in the household, being self-employed, the share of the mortgage value over total income, and the spread between the Eurirs and the Euribor. Marginal effects are reported graphically in Figures 3 and $4 .^{8}$

The interaction between financial literacy and the number of income earners in a household is not significant, indicating that the effect of the number of earners is not different across financial literacy levels. The same

${ }^{8}$ If we rewrite the model in equation 2 as

$$
P\left(y=1 \mid x_{1}, x_{2}, \mathbf{X}\right)=\Phi\left(\beta_{1} x_{1}+\beta_{2} x_{2}+\beta_{12} x_{1} x_{2}+\mathbf{X} \boldsymbol{\beta}_{j}\right)
$$

the marginal effect of the interaction (i.e., the marginal effect of $x_{1}$ as $x_{2}$ varies) is given by the cross-partial derivative of the dependent variable:

$$
\frac{\partial^{2} P\left(y=1 \mid x_{1}, x_{2}, \mathbf{X}\right)}{\partial x_{1} \partial x_{2}}=\beta_{12} \Phi^{\prime}(\cdot)+\left(\beta_{1}+\beta_{12} x_{2}\right)\left(\beta_{2}+\beta_{12} x_{1}\right) \Phi^{\prime \prime}(\cdot)
$$

Therefore, we cannot analyze the marginal effect of the interaction terms based on the marginal effects of Table 6 and must study it separately. 
is true for self-employed household heads. Therefore, we do not report the graphs for the marginal effects of these interaction terms. On the other hand, the interactions of the mortgage-to-income ratio and spread with financial literacy yield interesting results. Figure 3 reports the marginal effects of the mortgage-to-income ratio for various financial literacy levels. If we look at all households (first row of the graphs) and at relatively wealthier ones (bottom row), the marginal effect of the mortgage-to-income ratio increases only slightly with financial literacy. However, the effect appears to be more pronounced (though hardly statistically significant at the $5 \%$ level) for constrained individuals (wealth below the median). This can be interpreted as evidence that financially constrained households with higher mortgage-toincome ratios are more likely to have an ARM when they have low financial literacy, possibly because of lower initial payments. Conversely, when they have relatively greater financial literacy, they are more likely to choose an FRM (Figure 3 shows that the marginal effect becomes positive for literate households), presumably because they become aware of the higher exposure to income risk.

As for the interest rate spread, we know from Table 5 that a higher spread reduces the likelihood of an FRM, probably because households choose lower initial payments associated with ARMs (in times of positively sloped yield curves). Surprisingly, Figure 3 suggests that this effect is even larger for households with greater financial literacy.

\section{$5 \quad$ Mortgage delinquency}

The inability to regularly meet mortgage obligations can be due to unexpected events (e.g., job loss, health shock), but can also be the result of inappropriate choices made when taking out the mortgage, such as those analyzed in previous sections. Applying for a mortgage is a complex portfolio decision that involves evaluating several loan characteristics - such as maturity, the type of contract (ARM versus FRM), and the existence of cap options that limit the volatility of mortgage payments - as well as comparing the conditions offered by different intermediaries. Given this complexity, the possibility that the borrower engages in obligations that are too hard to comply with is always present, and a bad choice can increase the probability of not being able to repay one's debt. Financially illiterate individuals may incorrectly evaluate their mortgage burden and become over-indebted, and/or may be less aware of the riskiness of the mortgage and the correlation of these risks with the specific household. Conversely, financial literacy 
can result in a better ability to screen and compare mortgage conditions, thereby reducing the likelihood of being steered into unfavourable contract terms.

\subsection{Empirical strategy}

To analyse mortgage misconduct, we exploit the following question from the 2008 wave of the SHIW.

Considering loans of all types, was the household behind with payments by more than 90 days at any time last year?

Since the question refers to loans in general, we restrict our sample to those households that are homeowners and have a mortgage granted on or after $2000(N=589)$. We impose this additional restriction to the sample to avoid a selection problem (i.e., we observe in 2008 only mortgages that had not yet been repaid, and thus of longer duration). This restriction should be sufficient to avoid a selection bias, since $70 \%$ of mortgages concluded in recent years had a maturity of at least 10 years.

Moreover, bearing in mind that the question about delay does not differentiate between types of loans, we note that in our estimation sample $(N=$ 589 ) there are 477 households with mortgages only and 112 households with both a mortgage and a consumer loan. In a robustness check, we exclude from the sample households with a consumer loan, so that the answer about delay necessarily refers to those with only a household mortgage.

As before, we estimate a probit model:

$$
P(y=1 \mid \mathbf{X})=\Phi\left(\mathbf{X} \boldsymbol{\beta}_{j}\right)
$$

where the dependent variable is the probability that the respondent answered positively to the above question $(y=1)$. Summary statistics for this sample are shown in Table 1 (Panel C). About 3.7\% of households with a mortgage taken out on or after 2000 experienced a delay in 2008 in repaying it. The indicator of financial literacy is based on four questions (bank statement, inflation, risk diversification, and risky assets) and is measured in two alternative ways: through a dummy variable taking the value of one if the respondent gave four correct answers, and zero otherwise, and the number of correct answers (from zero to four). A total of $35 \%$ of the sample answered all four questions correctly, and the average number of correct answers was about 2.8. The other explanatory variables in equation (3) include gender (a dummy for male respondents), age, the education of the household head 
(years of schooling), dummies indicating the macro region of residence, a dummy indicating whether the household head is unemployed, total household income, a dummy taking the value of one if the household has positive liquid wealth, and zero otherwise, and mortgage characteristics such as the year the mortgage was taken out, whether it is an ARM, the total loan amount, and its maturity. ${ }^{9}$

\subsection{Results}

Marginal effects of the probit model for the probability of being behind schedule with mortgage payments are reported in Table 7 . Table 7 presents five specifications: The first includes demographic and socioeconomic variables only and the others include financial literacy. In columns II and III, financial literacy is a dummy indicating four correct answers, in columns IV and $\mathrm{V}$ it is measured as the number of correct answers, while in columns III and $\mathrm{V}$ financial literacy is interacted with the ratio of the monthly mortgage payment to household income.

It is worth noting, first, that the delay is not significantly affected by sociodemographic variables such as gender, age, education, and region of residence. Household income is not significant either, while having positive financial wealth significantly decreases the probability of delay (by about seven to eight percentage points, according to specifications). To some extent, these findings are consistent with the results of Magri and Pico (2010), who study mortgage delinquency in Italy using the European Union Statistics on Income and Living Conditions (EU-SILC) database for the years 2005-2007 and find age, gender, occupation, health status, and income level to be not statistically significant, with higher education reducing the probability of being behind with payments.

As for loan characteristics, having an ARM reduces the probability of being late with payments, probably because during 2008 short-term rates (taken as a reference for ARMs) dropped considerably, thus reducing the size of monthly repayments. Other mortgage characteristics, such as the total amount and maturity, are not significant. All specifications include dummies for the year the mortgage was taken out (not shown in Table 7) to control for market characteristics at that time (interest rates, business cycle, etc.).

Financial literacy reduces the probability of delay in column II of Table

\footnotetext{
${ }^{9}$ We are not able to control for other potentially important factors, such as the duration of the bank-household relationship. A longer relationship may allow the bank to gather 'soft information' about the borrower and lead to more favourable lending conditions.
} 
7 - being able to give four correct answers reduces the probability of being late by about two percentage points - but is not significant in specification IV. To further investigate the issue, we interact financial literacy with the incidence of mortgage payments on labour income (columns III and V). Even though mortgage characteristics taken one by one are not significant (with the exception of having an ARM), higher payment-to-income ratios are associated with higher probabilities of delay, probably because they summarize the extent of the burden better than other features. Moreover, this effect is higher for low-literacy households than for high-literacy ones (even though the interaction term is not significant in column III). This evidence suggests that the incorrect evaluation of the mortgage burden by financially illiterate respondents can drive the delay in mortgage repayments.

As anticipated, we perform the same estimations on the sample of households that have a mortgage and no consumer loans at the time of the interview (results available upon request) to verify that the above results are not driven by households having both a housing and a consumer loan. We find that the results for financial literacy (and for most covariates) are unchanged, thus confirming our previous results.

\section{Conclusion}

Basic financial understanding and ability are increasingly recognized as an essential part of citizens' stock of knowledge. While much effort has been devoted to measure financial (il)literacy, provide international comparisons, and investigate the relation between financial literacy and households' saving and investment decisions, the channels through which these effects are exerted are still very much unknown.

Our paper contributes to the literature by concentrating on the effects of financial (il)literacy on household choices with respect to taking out a house mortgage and the subsequent fulfilment of its obligations. We use Italian data to investigate the role of financial literacy on i) the choice of mortgage provider, ii) the choice between fixed and adjustable interest rate mortgages, and iii) delays in mortgage payments.

Regarding the first aspect, our results show that - consistent with our hypothesis that financial literacy enables consumers to select financial products according to the relevant aspects - financial literacy increases the probability of choosing better economic conditions and at the same time decreases that of not comparing options. Regarding the second aspect, we find that greater financial literacy improves households' ability to correctly evaluate 
their risk exposure in the choice between ARMs and FRMs. Finally, the third part of our empirical analysis suggests that financial literacy reduces the probability of delays in payments, although this result is not significant in all specifications of the estimation model.

From a policy perspective, these results stress the importance of actions aimed at increasing households' financial literacy as an effective instrument to improve their decision making and, ultimately, their welfare.

\section{References}

Atkinson, A., S. McKay, E. Kempson, and S. Collard (2006). Levels of financial capability in the UK: Results of a baseline survey. Consumer Research 47, Financial Services Authority.

Brueckner, J. K. and J. R. Follain (1988). The rise and fall of the ARM: An econometric analysis of mortgage choice. The Review of Economics and Statistics $70(1)$, pp. 93-102.

Bucher-Koenen, T. and A. Lusardi (2011). Financial literacy and retirement planning in Germany. Journal of Pension Economics and Finance 10(4), (forthcoming).

Bucks, B. and K. Pence (2008). Do borrowers know their mortgage terms? Journal of Urban Economics 64(2).

Campbell, J. Y. and J. F. Cocco (2003). Household risk management and optimal mortgage choice. The Quarterly Journal of Economics 118(4).

Casolaro, L., L. Gambacorta, and L. Guiso (2006). Regulation, formal and informal enforcement, and the development of the household loan market: lesson from Italy. In G. Bertola, R. Disney, and C. Grant (Eds.), The economics of consumer credit. The MIT Press.

Dhillon, U. S., J. D. Shilling, and C. F. Sirmans (1987). Choosing between fixed and adjustable rate mortgages: Note. Journal of Money, Credit and Banking 19(2).

Duca, J. V. and A. Kumar (2010). Financial literacy and mortgage equity withdrawals. Mimeo.

FINRA Investor Education Foundation (2009). Financial Capability in the United States. National Survey - Executive Summary. Washington, D.C.: FINRA Investor Education Foundation. 
Fornero, E. and C. Monticone (2011). Financial literacy and pension plan participation in Italy. Journal of Pension Economics and Finance 10(4), $547-564$.

Gerardi, K., L. Goette, and S. Meier (2010). Financial literacy and subprime mortgage delinquency: Evidence from a survey matched to administrative data. Working Paper 2010-10, Federal Reserve Bank of Atlanta.

Guiso, L. and T. Jappelli (2008). Financial literacy and portfolio diversification. EUI Working Paper ECO 2008/31.

Hastings, J. S. and L. Tejeda-Ashton (2008). Financial literacy, information, and demand elasticity: Survey and experimental evidence from Mexico. NBER Working Paper 14538, National Bureau of Economic Research.

Hung, A. A., A. M. Parker, and J. K. Yoong (2009). Defining and measuring financial literacy. Working Paper WR-708, RAND Working Paper.

Jappelli, T. (2010). Economic literacy: An international comparison. The Economic Journal 120(548), F429-F451.

Kimball, M. S. and T. Shumway (2007). Investor sophistication and the home bias, diversifcation, and employer stock puzzles. Mimeo, University of Michigan.

Lusardi, A. and O. Mitchell (2006). Financial literacy and planning: Implications for retirement wellbeing. PRC Working Paper No. 1/2006.

Lusardi, A. and O. Mitchell (2011). Financial literacy and planning: Implications for retirement wellbeing. In A. Lusardi and O. Mitchell (Eds.), Financial Literacy: Implications for Retirement Security and the Financial Marketplace. Oxford: Oxford University Press.

Lusardi, A. and O. S. Mitchell (2007). Baby boomer retirement security: The roles of planning, financial literacy, and housing wealth. Journal of Monetary Economics 54(1), 205-224.

Lusardi, A. and P. Tufano (2009). Debt literacy, financial experiences, and overindebtedness. Working Paper 14808, NBER.

Magri, S. and R. Pico (2010). The rise of risk-based pricing of mortgage interest rates in Italy. Working Paper No 778, Banca d'Italia.

Monticone, C. (2010). How much does wealth matter in the acquisition of financial literacy? Journal of Consumer Affairs 44(2), 403-422. 
Nöth, M. and T. Puhan (2009). How to hide mutual fund fees - experimental evidence. Working paper, University of Hamburg.

Paiella, M. and A. Pozzolo (2007). Choosing between fixed and adjustable rate mortgages. In B. Ambrose and S. Agarwal (Eds.), Household Financial Decision Making. NY: Palgrave MacMillian Ltd.

President's Advisory Council on Financial Literacy (2008). 2008 Annual Report to the President. The Department of the Treasury.

Rossi, P. (2008). L'offerta di mutui alle famiglie: caratteristiche, evoluzione e differenze territoriali. i risultati di un'indagine campionaria. Questioni di Economia e Finanza - Occasional papers 13, Bank of Italy.

van Rooij, M., A. Lusardi, and R. Alessie (2008). Financial literacy, retirement planning, and household wealth. Paper presented at the ECB-CFS Conference on Household Finances and Consumption, Frankfurt am Main, Germany, September 4-5, 2008.

van Rooij, M., A. Lusardi, and R. Alessie (2011). Financial literacy and stock market participation. Journal of Financial Economics 101 (2), 449472. 


\section{A Tables and Figures}

\begin{tabular}{|c|c|c|c|c|c|}
\hline \multicolumn{6}{|c|}{$\begin{array}{l}\text { National Saving Bank } \\
\text { Account statement as of 31/05/200 } \\
\text { Account No } 678987654321\end{array}$} \\
\hline DATE & VALUE & REF. & DESCRIPTION & WITHDRAWALS & DEPOSITS \\
\hline$* * *$ & $* * *$ & $* * *$ & PREVIOUS BALANCE AS OF 05/05/2006 & & 320 \\
\hline 01/05/2006 & 30/04/2006 & 1007 & PHONE BILL PAYMENT, PERIOD 01/03/2006 - 30/04/2006 & 65 & \\
\hline 02/05/2006 & 01/05/2006 & 1008 & WITHDRAWAL DEBIT CARD N. 10 & 100 & \\
\hline 27/05/2006 & 28/05/2006 & 1010 & PAYROLL DEPOSIT & & 1.100 \\
\hline 28/05/2006 & 27/05/2006 & 1011 & $\begin{array}{l}\text { CHEQUE N. } 3036 \\
\text { YOUR ORDER IN FAVOR OF MR PAOLO ROSSI }\end{array}$ & 187 & \\
\hline 29/05/2006 & 28/05/2006 & 1012 & RENT PAYMENT APRIL & 800 & \\
\hline 29/05/2006 & 28/05/2006 & 1013 & FEES FOR TRANSACTION No 1012 & 1 & \\
\hline 31/05/2006 & 30/05/2006 & 1014 & $\begin{array}{l}\text { PURCHASE CARD N. } 10 . \\
\text { ON 28/05/2006 CHEMIST SHOP }\end{array}$ & 88 & \\
\hline 31/05/2006 & 30/05/2006 & 1015 & REFUND NURSERY SCHOOL FEES & & 100 \\
\hline **** & $* * *$ & $* * *$ & BALANCE AFTER THE ABOVE MENTIONED TRANSACTIONS & & 279 \\
\hline
\end{tabular}

Figure 1: Figure for Question 1

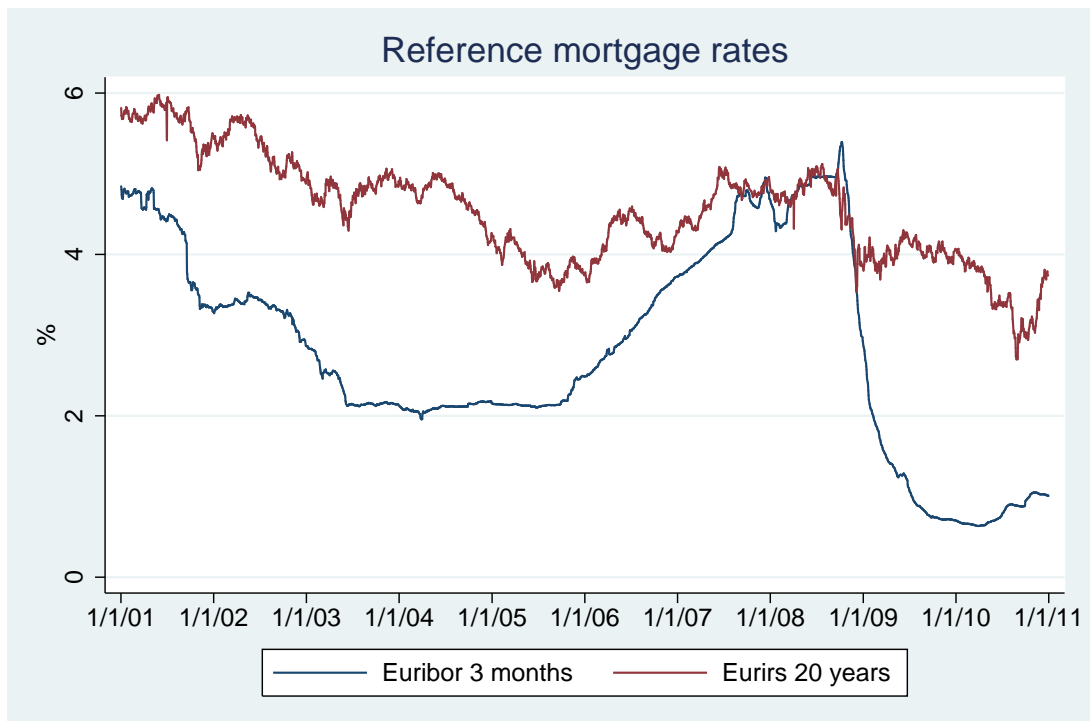

Figure 2: Reference mortgage interest rates (2001-2010) 

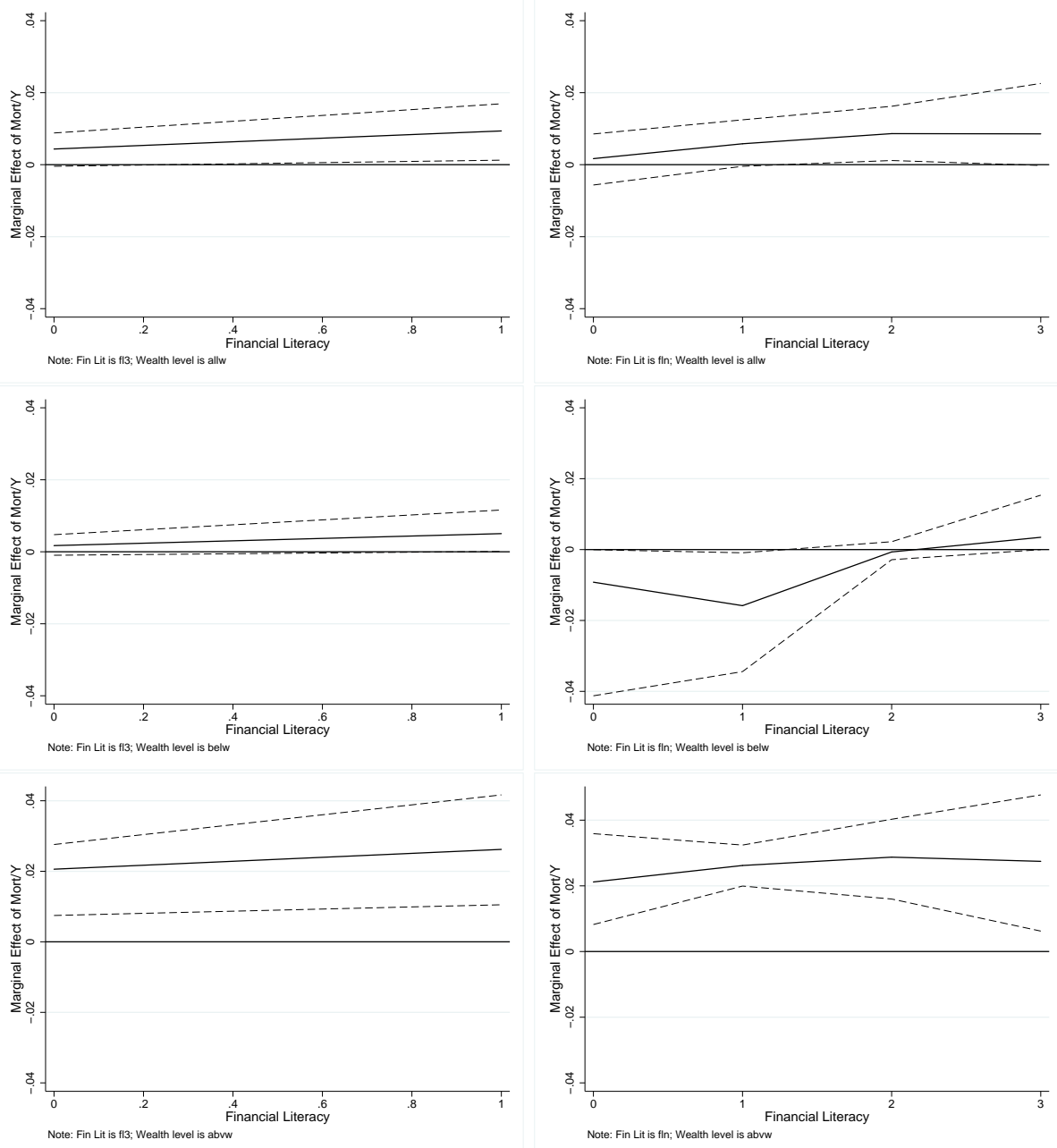

Note: The tables in the first row are referred to all wealth levels; tables in the second row refer to households with wealth below the median; tables in the bottom row refer to households with wealth above the median. Tables in the left column use as a measure for financial literacy a dummy variable taking the value of one for three correct answers; tables on the right use as a measure for financial literacy the number of correct answers.

Figure 3: Interaction effects (Mortgage-to-Income ratio) 

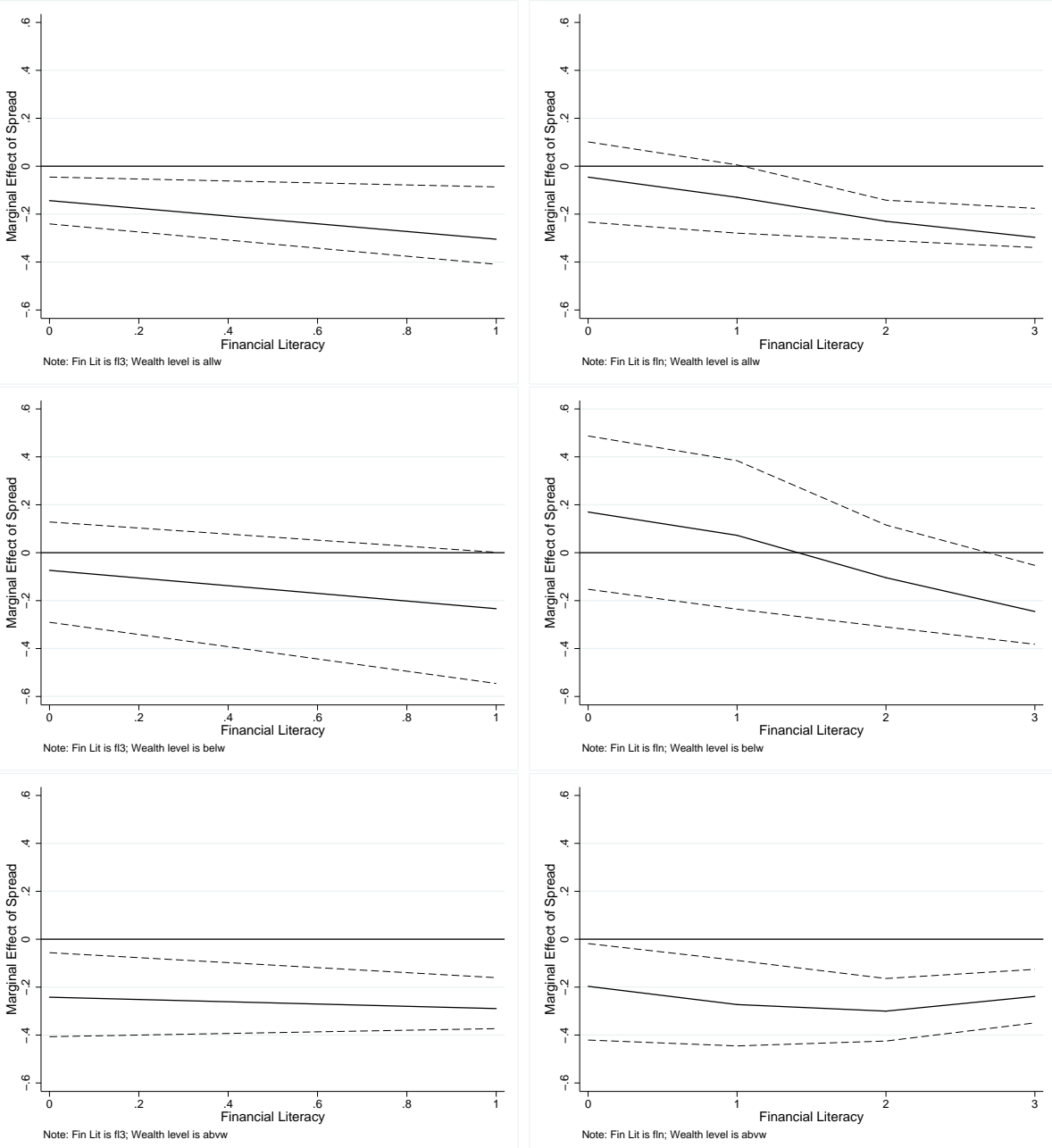

Note: The tables in the first row are referred to all wealth levels; tables in the second row refer to households with wealth below the median; tables in the bottom row refer to households with wealth above the median. Tables in the left column use as a measure for financial literacy a dummy variable taking the value of one for three correct answers; tables on the right use as a measure for financial literacy the number of correct answers.

Figure 4: Interaction effects (Interest rate spread) 
Table 1: Summary statistics

\begin{tabular}{|c|c|c|c|}
\hline & Mean & Median & Std. Dev. \\
\hline \multicolumn{4}{|c|}{ Panel A - Part $1(N=148)$} \\
\hline Choice of mortgage lender - Alt 1 & 0.61 & 1 & 0.49 \\
\hline Choice of mortgage lender - Alt 2 & 0.1 & 0 & 0.3 \\
\hline Choice of mortgage lender - Alt 3 & 0.05 & 0 & 0.23 \\
\hline Choice of mortgage lender - Alt 4 & 0.23 & 0 & 0.42 \\
\hline Male (dummy) & 0.72 & 1 & 0.45 \\
\hline Age & 46.41 & 46 & 12.68 \\
\hline $\mathrm{N}$ income earners & 1.84 & 2 & 0.72 \\
\hline $\mathrm{N}$ hh components & 3.04 & 3 & 1.26 \\
\hline Years schooling & 10.94 & 11 & 4.38 \\
\hline North-West (dummy) & 0.14 & 0 & 0.35 \\
\hline North-East (dummy) & 0.31 & 0 & 0.46 \\
\hline Center (dummy) & 0.22 & 0 & 0.42 \\
\hline Unemployed (dummy) & 0.03 & 0 & 0.16 \\
\hline Income from labour/pensions (th. euro) & 30.73 & 27.56 & 16.32 \\
\hline Liquid wealth > 0 (dummy) & 0.82 & 1 & 0.38 \\
\hline FL: 4 correct (dummy) & 0.29 & 0 & 0.46 \\
\hline FL: $N$ correct (out of 4 ) & 2.56 & 3 & 1.23 \\
\hline \multicolumn{4}{|c|}{ Panel B - Part 2 $(N=170)$} \\
\hline FRM (dummy) & 0.52 & 1 & 0.5 \\
\hline Male (dummy) & 0.71 & 1 & 0.45 \\
\hline Age & 42.45 & 40 & 11.44 \\
\hline $\mathrm{N}$ income earners & 1.74 & 2 & 0.67 \\
\hline $\mathrm{N}$ hh components & 2.84 & 3 & 1.21 \\
\hline Years schooling & 11.62 & 13 & 3.97 \\
\hline Self-employed (dummy) & 0.17 & 0 & 0.38 \\
\hline North-West (dummy) & 0.22 & 0 & 0.42 \\
\hline North-East (dummy) & 0.35 & 0 & 0.48 \\
\hline Center (dummy) & 0.19 & 0 & 0.39 \\
\hline High risk aversion & 0.39 & 0 & 0.49 \\
\hline Mortgage/total income & 5.88 & 3.92 & 16.72 \\
\hline Liquid wealth (th. euro) & 27.05 & 6.31 & 138.55 \\
\hline Interest rate spread (Eurirs 20y - Euribor 3m) & 0.82 & 0.41 & 0.66 \\
\hline Per capita GDP & 26.94 & 26.3 & 0.81 \\
\hline FL: 3 correct (dummy) & 0.41 & 0 & 0.49 \\
\hline FL: $N$ correct (out of 3 ) & 1.71 & 2 & 1.29 \\
\hline \multicolumn{4}{|c|}{ Panel $C$ - Part $2(N=589)$} \\
\hline Delay (dummy) & 0.04 & 0 & 0.19 \\
\hline Male (dummy) & 0.69 & 1 & 0.46 \\
\hline Age & 46.52 & 45 & 11.47 \\
\hline Years schooling & 11.44 & 13 & 4.25 \\
\hline North-West (dummy) & 0.21 & 0 & 0.41 \\
\hline North-East (dummy) & 0.33 & 0 & 0.47 \\
\hline Center (dummy) & 0.19 & 0 & 0.39 \\
\hline Unemployed (dummy) & 0.03 & 0 & 0.17 \\
\hline Income from labour/pensions (th. euro) & 34.13 & 29.65 & 25.86 \\
\hline Liquid wealth $>0$ (dummy) & 0.85 & 1 & 0.36 \\
\hline ARM (dummy) & 0.43 & 0 & 0.5 \\
\hline Total mortgage amount & 89.29 & 80 & 57.47 \\
\hline Mortgage maturity & 16.47 & 15 & 7.25 \\
\hline FL: 4 correct (dummy) & 0.35 & 0 & 0.48 \\
\hline FL: $N$ correct (out of 4 ) & 2.76 & 3 & 1.2 \\
\hline
\end{tabular}


Table 2: Part I - Choice of mortgage lender

\begin{tabular}{|c|c|c|c|c|}
\hline & $\begin{array}{c}\text { Alt } 1 \\
\text { (I) }\end{array}$ & $\begin{array}{c}\text { Alt } 2 \\
\text { (II) }\end{array}$ & $\begin{array}{l}\text { Alt } 3 \\
\text { (III) }\end{array}$ & $\begin{array}{l}\text { Alt } 4 \\
(\mathrm{IV})\end{array}$ \\
\hline \multirow[t]{2}{*}{ Male } & 0.063 & 0.028 & -0.021 & -0.070 \\
\hline & $(0.09)$ & $(0.02)$ & $(0.02)$ & $(0.09)$ \\
\hline \multirow[t]{2}{*}{ Age } & -0.000 & -0.000 & -0.000 & 0.000 \\
\hline & $(0.00)$ & $(0.00)$ & $(0.00)$ & $(0.00)$ \\
\hline \multirow[t]{2}{*}{$\mathrm{N}$ income earners } & -0.089 & -0.001 & 0.006 & 0.085 \\
\hline & $(0.07)$ & $(0.02)$ & $(0.01)$ & $(0.06)$ \\
\hline \multirow[t]{2}{*}{ Num H components } & 0.007 & 0.004 & 0.003 & -0.014 \\
\hline & $(0.03)$ & $(0.01)$ & $(0.01)$ & $(0.03)$ \\
\hline \multirow[t]{2}{*}{ Years schooling } & 0.010 & -0.002 & -0.003 & -0.006 \\
\hline & $(0.01)$ & $(0.00)$ & $(0.00)$ & $(0.01)$ \\
\hline \multirow{2}{*}{ North-west } & -0.140 & 0.048 & 0.010 & 0.081 \\
\hline & $(0.15)$ & $(0.06)$ & $(0.03)$ & $(0.14)$ \\
\hline \multirow[t]{2}{*}{ North-east } & $0.219^{* * *}$ & -0.047 & 0.015 & $-0.187^{* *}$ \\
\hline & $(0.08)$ & $(0.03)$ & $(0.02)$ & $(0.08)$ \\
\hline \multirow[t]{2}{*}{ Center } & 0.019 & -0.010 & -0.003 & -0.006 \\
\hline & $(0.10)$ & $(0.02)$ & $(0.02)$ & $(0.10)$ \\
\hline \multirow[t]{2}{*}{ Unemployed } & $-0.450 * * *$ & $-0.082^{* *}$ & $-0.033^{* *}$ & $0.565^{* * *}$ \\
\hline & $(0.16)$ & $(0.03)$ & $(0.02)$ & $(0.15)$ \\
\hline \multirow[t]{2}{*}{ Income labour/pens } & 0.005 & $0.001^{*}$ & -0.001 & -0.006 \\
\hline & $(0.00)$ & $(0.00)$ & $(0.00)$ & $(0.00)$ \\
\hline \multirow[t]{2}{*}{ Fin wealth $>0$} & -0.073 & -0.013 & 0.007 & 0.079 \\
\hline & $(0.10)$ & $(0.03)$ & $(0.01)$ & $(0.10)$ \\
\hline \multirow[t]{2}{*}{$4 / 4$ correct } & $0.184^{* *}$ & -0.024 & -0.003 & $-0.156^{* *}$ \\
\hline & $(0.08)$ & $(0.02)$ & $(0.02)$ & $(0.07)$ \\
\hline $\mathrm{N}$ obs & 148 & 148 & 148 & 148 \\
\hline Predicted prob. & 73.83 & 3.80 & 1.50 & 20.88 \\
\hline Observed prob. & 61.49 & 10.14 & 5.41 & 22.97 \\
\hline
\end{tabular}

Notes: Significance level ${ }^{*} p<0.1,{ }^{* *} p<0.05,{ }^{* * *} p<0.01$. The table reports marginal effects. Standard errors in brackets are robust to heteroskedasticity. Alternatives:

1. It offered better financial conditions than competitors

2. It offered better non-financial conditions than competitors (e.g. rapid processing)

3. It was the only one to grant the loan

4. It was the first institution I contacted 
Table 3: Part I - Choice of mortgage lender

\begin{tabular}{|c|c|c|c|c|}
\hline & $\begin{array}{c}\text { Alt } 1 \\
\text { (I) }\end{array}$ & $\begin{array}{c}\text { Alt 2 } \\
\text { (II) }\end{array}$ & $\begin{array}{c}\text { Alt } 3 \\
\text { (III) }\end{array}$ & $\begin{array}{l}\text { Alt } 4 \\
\text { (IV) }\end{array}$ \\
\hline \multirow[t]{2}{*}{ Male } & 0.074 & 0.027 & -0.020 & -0.081 \\
\hline & $(0.09)$ & $(0.02)$ & $(0.02)$ & $(0.09)$ \\
\hline \multirow[t]{2}{*}{ Age } & -0.000 & -0.000 & -0.000 & 0.000 \\
\hline & $(0.00)$ & $(0.00)$ & $(0.00)$ & $(0.00)$ \\
\hline \multirow[t]{2}{*}{$\mathrm{N}$ income earners } & -0.099 & 0.001 & 0.005 & 0.093 \\
\hline & $(0.07)$ & $(0.02)$ & $(0.01)$ & $(0.07)$ \\
\hline \multirow[t]{2}{*}{ Num H components } & 0.002 & 0.004 & 0.003 & -0.009 \\
\hline & $(0.03)$ & $(0.01)$ & $(0.01)$ & $(0.03)$ \\
\hline \multirow[t]{2}{*}{ Years schooling } & 0.011 & -0.001 & -0.003 & -0.006 \\
\hline & $(0.01)$ & $(0.00)$ & $(0.00)$ & $(0.01)$ \\
\hline \multirow[t]{2}{*}{ North-west } & -0.182 & 0.052 & 0.011 & 0.118 \\
\hline & $(0.14)$ & $(0.06)$ & $(0.03)$ & $(0.13)$ \\
\hline \multirow[t]{2}{*}{ North-east } & $0.206^{* *}$ & -0.042 & 0.014 & $-0.178^{* *}$ \\
\hline & $(0.09)$ & $(0.03)$ & $(0.02)$ & $(0.08)$ \\
\hline \multirow[t]{2}{*}{ Center } & 0.002 & -0.008 & -0.005 & 0.010 \\
\hline & $(0.10)$ & $(0.02)$ & $(0.02)$ & $(0.10)$ \\
\hline \multirow[t]{2}{*}{ Unemployed } & $-0.406^{* *}$ & $-0.082^{* * *}$ & $-0.033^{* *}$ & $0.520^{* * *}$ \\
\hline & $(0.17)$ & $(0.03)$ & $(0.01)$ & $(0.17)$ \\
\hline \multirow[t]{2}{*}{ Income labour/pens } & 0.006 & $0.001^{*}$ & -0.001 & -0.006 \\
\hline & $(0.00)$ & $(0.00)$ & $(0.00)$ & $(0.00)$ \\
\hline \multirow[t]{2}{*}{ Fin wealth $>0$} & -0.087 & -0.007 & 0.007 & 0.087 \\
\hline & $(0.10)$ & $(0.03)$ & $(0.01)$ & $(0.10)$ \\
\hline \multirow[t]{2}{*}{$\mathrm{N} / 4$ correct } & 0.050 & -0.011 & 0.002 & -0.041 \\
\hline & $(0.04)$ & $(0.01)$ & $(0.01)$ & $(0.03)$ \\
\hline $\mathrm{N}$ obs & 148 & 148 & 148 & 148 \\
\hline Predicted prob. & 73.46 & 3.66 & 1.44 & 21.44 \\
\hline Observed prob. & 61.49 & 10.14 & 5.41 & 22.97 \\
\hline
\end{tabular}

Notes: Significance level ${ }^{*} p<0.1,{ }^{* *} p<0.05,{ }^{* * *} p<0.01$. The table reports marginal effects. Standard errors in brackets are robust to heteroskedasticity. Alternatives:

1. It offered better financial conditions than competitors

2. It offered better non-financial conditions than competitors (e.g. rapid processing)

3. It was the only one to grant the loan

4. It was the first institution I contacted 
Table 4: Descriptive statistics of macro variables

\begin{tabular}{ccccc}
\hline \hline Year & $\begin{array}{c}\text { Eurirs } \\
(20 \text { years })\end{array}$ & $\begin{array}{c}\text { Euribor } \\
(3 \text { months })\end{array}$ & $\begin{array}{c}\text { Difference } \\
\text { (Eurirs-Euribor })\end{array}$ & $\begin{array}{c}\text { Per capita GDP } \\
\text { growth }\end{array}$ \\
\hline & & & & \\
2005 & 3.8926 & 2.1844 & 1.7082 & 24.4513 \\
2006 & 4.2068 & 3.0807 & 1.1261 & 25.2823 \\
2007 & 4.6903 & 4.2776 & 0.4127 & 26.1482 \\
2008 & 4.7064 & 4.6439 & 0.0625 & 26.2977 \\
\hline \hline
\end{tabular}


Table 5: Part II - Probability of choosing a FRM

\begin{tabular}{|c|c|c|c|c|c|c|}
\hline & \multicolumn{3}{|c|}{ FL: 3 correct $/ 3$} & \multicolumn{3}{|c|}{ FL: 3 correct $/ 3$} \\
\hline & $\begin{array}{c}\text { All W levels } \\
\text { (I) }\end{array}$ & $\begin{array}{c}<\text { Median W } \\
\text { (II) }\end{array}$ & $\begin{array}{c}>\text { Median W } \\
(\text { III })\end{array}$ & $\begin{array}{l}\text { All W levels } \\
\text { (IV) }\end{array}$ & $\begin{array}{c}<\text { Median W } \\
(\mathrm{V})\end{array}$ & $\begin{array}{c}>\text { Median W } \\
(\mathrm{VI})\end{array}$ \\
\hline \multirow[t]{2}{*}{ Male } & 0.001 & 0.139 & -0.203 & 0.016 & $0.196^{*}$ & -0.467 \\
\hline & $(0.07)$ & $(0.13)$ & $(0.17)$ & $(0.07)$ & $(0.12)$ & $(0.44)$ \\
\hline \multirow[t]{2}{*}{ Age } & 0.002 & 0.006 & -0.004 & 0.003 & 0.010 & -0.011 \\
\hline & $(0.00)$ & $(0.01)$ & $(0.00)$ & $(0.00)$ & $(0.01)$ & $(0.01)$ \\
\hline \multirow[t]{2}{*}{$\mathrm{N}$ income earners } & 0.060 & 0.049 & 0.043 & 0.048 & 0.052 & 0.069 \\
\hline & $(0.07)$ & $(0.05)$ & $(0.13)$ & $(0.07)$ & $(0.05)$ & $(0.33)$ \\
\hline \multirow[t]{2}{*}{$\mathrm{N}$ hh components } & 0.030 & 0.045 & $0.060^{* *}$ & 0.025 & 0.043 & $0.133^{* *}$ \\
\hline & $(0.04)$ & $(0.05)$ & $(0.03)$ & $(0.03)$ & $(0.07)$ & $(0.06)$ \\
\hline \multirow[t]{2}{*}{ Years education } & -0.014 & -0.004 & -0.022 & -0.014 & -0.004 & -0.056 \\
\hline & $(0.02)$ & $(0.02)$ & $(0.02)$ & $(0.02)$ & $(0.02)$ & $(0.04)$ \\
\hline \multirow[t]{2}{*}{ Self-employed } & -0.045 & 0.094 & $-0.153^{*}$ & -0.048 & 0.068 & $-0.358^{*}$ \\
\hline & $(0.13)$ & $(0.33)$ & $(0.08)$ & $(0.13)$ & $(0.33)$ & $(0.18)$ \\
\hline \multirow[t]{2}{*}{ North West } & $-0.208^{* *}$ & -0.406 & -0.226 & $-0.234^{* * *}$ & $-0.528^{*}$ & -0.595 \\
\hline & $(0.09)$ & $(0.32)$ & $(0.17)$ & $(0.09)$ & $(0.29)$ & $(0.48)$ \\
\hline \multirow[t]{2}{*}{ North East } & $-0.286^{* * *}$ & $-0.606^{* * *}$ & -0.188 & $-0.294^{* * *}$ & $-0.710 * * *$ & -0.436 \\
\hline & $(0.09)$ & $(0.13)$ & $(0.17)$ & $(0.09)$ & $(0.12)$ & $(0.41)$ \\
\hline \multirow[t]{2}{*}{ Centre } & 0.010 & -0.172 & -0.004 & 0.020 & -0.288 & 0.086 \\
\hline & $(0.09)$ & $(0.24)$ & $(0.20)$ & $(0.08)$ & $(0.25)$ & $(0.46)$ \\
\hline \multirow{2}{*}{ High risk aversion } & -0.070 & -0.183 & 0.006 & -0.067 & $-0.212^{*}$ & 0.026 \\
\hline & $(0.09)$ & $(0.12)$ & $(0.11)$ & $(0.09)$ & $(0.11)$ & $(0.26)$ \\
\hline \multirow[t]{2}{*}{ Mortgage/tot income } & $0.009^{* * *}$ & $0.005^{* * *}$ & $0.023^{* * *}$ & $0.009 * * *$ & $0.004^{* * *}$ & $0.056^{* * *}$ \\
\hline & $(0.00)$ & $(0.00)$ & $(0.00)$ & $(0.00)$ & $(0.00)$ & $(0.01)$ \\
\hline \multirow[t]{2}{*}{ Net liquid wealth } & -0.001 & -0.058 & -0.000 & -0.001 & -0.062 & -0.001 \\
\hline & $(0.00)$ & $(0.08)$ & $(0.00)$ & $(0.00)$ & $(0.06)$ & $(0.00)$ \\
\hline \multirow[t]{2}{*}{ Spread } & $-0.255^{* * *}$ & -0.152 & $-0.359 * * *$ & $-0.225^{* * *}$ & -0.046 & $-0.835^{* * *}$ \\
\hline & $(0.05)$ & $(0.13)$ & $(0.08)$ & $(0.06)$ & $(0.15)$ & $(0.23)$ \\
\hline \multirow[t]{2}{*}{ Real p.c. GDP growth } & $0.027^{*}$ & $-0.049^{*}$ & $0.094^{* *}$ & $0.029^{*}$ & -0.041 & $0.215^{*}$ \\
\hline & $(0.02)$ & $(0.03)$ & $(0.05)$ & $(0.02)$ & $(0.04)$ & $(0.12)$ \\
\hline \multirow[t]{2}{*}{ FL: 3 correct $/ 3$} & $0.236^{* *}$ & $0.389 * *$ & 0.191 & & & \\
\hline & $(0.10)$ & $(0.16)$ & $(0.16)$ & & & \\
\hline \multirow[t]{2}{*}{ FL: $N$ correct $/ 3$} & & & & $0.089 * *$ & $0.230 * * *$ & 0.131 \\
\hline & & & & $(0.04)$ & $(0.06)$ & $(0.16)$ \\
\hline $\mathrm{N}$ & 170 & 85 & 85 & 170 & 85 & 85 \\
\hline
\end{tabular}

Notes: Significance level ${ }^{*} p<0.1,{ }^{* *} p<0.05,{ }^{* * *} p<0.01$. The table reports marginal effects. Standard errors are in brackets. Errors are robust to heteroskedasticity and correlation of observations within the same year mortgage was taken out. Monetary variables are in 2008 thousand euro. 
Table 6: Part II - Probability of choosing a FRM

\begin{tabular}{|c|c|c|c|c|c|c|}
\hline & \multicolumn{3}{|c|}{ FL: 3 correct $/ 3$} & \multicolumn{3}{|c|}{ FL: 3 correct $/ 3$} \\
\hline & $\begin{array}{c}\text { All W levels } \\
\text { (I) }\end{array}$ & $\begin{array}{c}<\text { Median W } \\
(\mathrm{II})\end{array}$ & $\begin{array}{c}>\text { Median W } \\
(\text { III })\end{array}$ & $\begin{array}{l}\text { All W levels } \\
\text { (IV) }\end{array}$ & $\begin{array}{c}<\text { Median W } \\
(\mathrm{V})\end{array}$ & $\begin{array}{c}>\text { Median W } \\
(\mathrm{VI})\end{array}$ \\
\hline \multirow[t]{2}{*}{ Male } & 0.004 & 0.087 & -0.171 & -0.004 & 0.093 & -0.170 \\
\hline & $(0.07)$ & $(0.07)$ & $(0.17)$ & $(0.06)$ & $(0.07)$ & $(0.18)$ \\
\hline \multirow[t]{2}{*}{ Age } & 0.001 & 0.005 & -0.003 & 0.002 & 0.009 & -0.004 \\
\hline & $(0.00)$ & $(0.01)$ & $(0.00)$ & $(0.00)$ & $(0.01)$ & $(0.01)$ \\
\hline \multirow[t]{2}{*}{$\mathrm{N}$ income earners } & 0.031 & 0.012 & 0.035 & 0.079 & 0.005 & 0.155 \\
\hline & $(0.07)$ & $(0.11)$ & $(0.15)$ & $(0.07)$ & $(0.17)$ & $(0.13)$ \\
\hline \multirow[t]{2}{*}{$\mathrm{N}$ hh components } & 0.047 & 0.075 & $0.060 * * *$ & 0.037 & 0.079 & $0.052^{* *}$ \\
\hline & $(0.04)$ & $(0.06)$ & $(0.02)$ & $(0.03)$ & $(0.09)$ & $(0.02)$ \\
\hline \multirow[t]{2}{*}{ Years education } & -0.014 & -0.006 & -0.021 & -0.015 & -0.009 & -0.023 \\
\hline & $(0.01)$ & $(0.01)$ & $(0.01)$ & $(0.02)$ & $(0.01)$ & $(0.02)$ \\
\hline \multirow[t]{2}{*}{ Self-employed } & -0.097 & 0.269 & $-0.338^{* *}$ & -0.010 & $0.454^{* *}$ & $-0.396^{*}$ \\
\hline & $(0.19)$ & $(0.21)$ & $(0.15)$ & $(0.25)$ & $(0.19)$ & $(0.21)$ \\
\hline \multirow[t]{2}{*}{ North West } & $-0.224^{* * *}$ & -0.438 & -0.231 & $-0.260 * * *$ & $-0.636^{* *}$ & -0.235 \\
\hline & $(0.09)$ & $(0.33)$ & $(0.16)$ & $(0.09)$ & $(0.26)$ & $(0.17)$ \\
\hline \multirow[t]{2}{*}{ North East } & $-0.306 * * *$ & $-0.619 * * *$ & -0.206 & $-0.313^{* * *}$ & $-0.780 * * *$ & -0.202 \\
\hline & $(0.08)$ & $(0.14)$ & $(0.16)$ & $(0.08)$ & $(0.10)$ & $(0.15)$ \\
\hline \multirow[t]{2}{*}{ Centre } & -0.018 & -0.236 & 0.001 & -0.022 & $-0.490^{* *}$ & 0.023 \\
\hline & $(0.10)$ & $(0.28)$ & $(0.19)$ & $(0.08)$ & $(0.21)$ & $(0.20)$ \\
\hline \multirow[t]{2}{*}{ High risk aversion } & -0.085 & $-0.212^{* * *}$ & -0.018 & -0.067 & -0.137 & -0.021 \\
\hline & $(0.10)$ & $(0.08)$ & $(0.11)$ & $(0.09)$ & $(0.15)$ & $(0.09)$ \\
\hline \multirow[t]{2}{*}{ Mortgage/tot income } & $0.005^{*}$ & 0.002 & $0.022 * * *$ & 0.004 & $-0.035^{* *}$ & $0.026^{* * *}$ \\
\hline & $(0.00)$ & $(0.00)$ & $(0.01)$ & $(0.01)$ & $(0.02)$ & $(0.01)$ \\
\hline \multirow[t]{2}{*}{ Net liquid wealth } & $-0.001^{* * *}$ & -0.066 & $-0.000^{* * *}$ & $-0.001^{* *}$ & -0.055 & $-0.000^{*}$ \\
\hline & $(0.00)$ & $(0.08)$ & $(0.00)$ & $(0.00)$ & $(0.08)$ & $(0.00)$ \\
\hline \multirow[t]{2}{*}{ Spread } & $-0.164^{* * *}$ & -0.086 & $-0.343^{* *}$ & -0.056 & 0.264 & $-0.468^{* *}$ \\
\hline & $(0.05)$ & $(0.12)$ & $(0.14)$ & $(0.11)$ & $(0.23)$ & $(0.23)$ \\
\hline \multirow[t]{2}{*}{ Real p.c. GDP growth } & $0.033^{* *}$ & -0.042 & $0.093^{* *}$ & $0.045^{* *}$ & 0.000 & $0.083^{* *}$ \\
\hline & $(0.02)$ & $(0.03)$ & $(0.04)$ & $(0.02)$ & $(0.04)$ & $(0.04)$ \\
\hline \multirow[t]{2}{*}{ FL: 3 correct $/ 3$} & 0.264 & 0.294 & 0.095 & & & \\
\hline & $(0.40)$ & $(0.59)$ & $(0.23)$ & & & \\
\hline \multirow[t]{2}{*}{ FL 3 corr ${ }^{*} \mathrm{~N}$ earn } & 0.074 & 0.221 & 0.019 & & & \\
\hline & $(0.26)$ & $(0.42)$ & $(0.15)$ & & & \\
\hline \multirow[t]{2}{*}{ FL 3 corr $*$ Self-emp } & 0.053 & $-0.460 *$ & 0.319 & & & \\
\hline & $(0.26)$ & $(0.25)$ & $(0.21)$ & & & \\
\hline \multirow[t]{2}{*}{ FL 3 corr $*$ mtg/inc } & 0.006 & $0.006^{*}$ & 0.005 & & & \\
\hline & $(0.01)$ & $(0.00)$ & $(0.01)$ & & & \\
\hline FL 3 corr $*$ Spread & $-0.272^{* * *}$ & $-0.350^{*}$ & -0.018 & & & \\
\hline & $(0.09)$ & $(0.21)$ & $(0.17)$ & & & \\
\hline FL: $N$ correct $/ 3$ & & & & 0.237 & $0.393^{* *}$ & 0.104 \\
\hline & & & & $(0.15)$ & $(0.17)$ & $(0.09)$ \\
\hline $\mathrm{FL} \mathrm{N}$ corr $* \mathrm{~N}$ earn & & & & -0.034 & -0.015 & $-0.083^{* * *}$ \\
\hline & & & & $(0.06)$ & $(0.06)$ & $(0.01)$ \\
\hline FL N corr $*$ Self-emp & & & & -0.017 & $-0.230^{* *}$ & $0.136^{*}$ \\
\hline & & & & $(0.06)$ & $(0.10)$ & $(0.08)$ \\
\hline FL $\mathrm{N}$ corr ${ }^{*} \mathrm{mtg} / \mathrm{inc}$ & & & & 0.003 & $0.017^{* *}$ & 0.002 \\
\hline & & & 30 & $(0.00)$ & $(0.01)$ & $(0.01)$ \\
\hline FL N corr $*$ Spread & & & & $-0.091 * * *$ & $-0.185^{* * *}$ & 0.073 \\
\hline & & & & $(0.04)$ & $(0.05)$ & $(0.08)$ \\
\hline $\mathrm{N}$ & 170 & 85 & 85 & 170 & 85 & 85 \\
\hline
\end{tabular}

Notes: Significance level ${ }^{*} p<0.1,{ }^{* *} p<0.05,{ }^{* * *} p<0.01$. The table reports marginal effects. Standard errors are in brackets. Errors are robust to heteroskedasticity and correlation of observations within the same year mortgage was taken out. Monetary variables are in 2008 thousand euro. 
Table 7: Part III - Probability of delay

\begin{tabular}{|c|c|c|c|c|c|}
\hline & (I) & (II) & (III) & (IV) & $(\mathrm{V})$ \\
\hline \multirow[t]{2}{*}{ Male } & 0.005 & 0.005 & 0.003 & 0.006 & 0.004 \\
\hline & $(0.01)$ & $(0.01)$ & $(0.01)$ & $(0.01)$ & $(0.01)$ \\
\hline \multirow[t]{2}{*}{ Age } & -0.000 & -0.000 & -0.000 & -0.000 & -0.000 \\
\hline & $(0.00)$ & $(0.00)$ & $(0.00)$ & $(0.00)$ & $(0.00)$ \\
\hline \multirow{2}{*}{ Years education } & $-0.002^{*}$ & -0.002 & -0.002 & -0.002 & -0.002 \\
\hline & $(0.00)$ & $(0.00)$ & $(0.00)$ & $(0.00)$ & $(0.00)$ \\
\hline \multirow{2}{*}{ North West } & 0.012 & 0.011 & 0.008 & 0.014 & 0.011 \\
\hline & $(0.02)$ & $(0.02)$ & $(0.01)$ & $(0.02)$ & $(0.02)$ \\
\hline \multirow[t]{2}{*}{ North East } & 0.025 & 0.025 & 0.025 & 0.028 & 0.027 \\
\hline & $(0.02)$ & $(0.02)$ & $(0.02)$ & $(0.02)$ & $(0.02)$ \\
\hline \multirow[t]{2}{*}{ Centre } & 0.010 & 0.011 & 0.012 & 0.014 & 0.015 \\
\hline & $(0.02)$ & $(0.02)$ & $(0.02)$ & $(0.02)$ & $(0.02)$ \\
\hline \multirow[t]{2}{*}{ Unemployed } & 0.027 & 0.021 & -0.004 & 0.029 & -0.002 \\
\hline & $(0.04)$ & $(0.03)$ & $(0.01)$ & $(0.04)$ & $(0.02)$ \\
\hline \multirow{2}{*}{ Income } & -0.000 & -0.000 & -0.000 & -0.000 & -0.000 \\
\hline & $(0.00)$ & $(0.00)$ & $(0.00)$ & $(0.00)$ & $(0.00)$ \\
\hline \multirow[t]{2}{*}{ Fin wealth $>0$} & $-0.077^{* *}$ & $-0.074^{* *}$ & $-0.072^{* *}$ & $-0.079^{* *}$ & $-0.082^{* *}$ \\
\hline & $(0.03)$ & $(0.03)$ & $(0.03)$ & $(0.03)$ & $(0.03)$ \\
\hline \multirow[t]{2}{*}{ Has ARM } & $-0.017^{*}$ & $-0.015^{*}$ & $-0.015^{*}$ & $-0.015^{*}$ & $-0.016^{*}$ \\
\hline & $(0.01)$ & $(0.01)$ & $(0.01)$ & $(0.01)$ & $(0.01)$ \\
\hline \multirow[t]{2}{*}{ Tot amount mort } & 0.000 & -0.000 & -0.000 & -0.000 & -0.000 \\
\hline & $(0.00)$ & $(0.00)$ & $(0.00)$ & $(0.00)$ & $(0.00)$ \\
\hline \multirow[t]{2}{*}{ Mort maturity } & 0.001 & 0.001 & 0.001 & 0.001 & 0.001 \\
\hline & $(0.00)$ & $(0.00)$ & $(0.00)$ & $(0.00)$ & $(0.00)$ \\
\hline \multirow[t]{2}{*}{ FL: 4 correct/ 4} & & $-0.018^{* *}$ & -0.002 & & \\
\hline & & $(0.01)$ & $(0.01)$ & & \\
\hline \multirow[t]{2}{*}{ FL: N correct/4 } & & & & -0.005 & 0.001 \\
\hline & & & & $(0.00)$ & $(0.00)$ \\
\hline \multirow[t]{2}{*}{ Mort paym/ylab } & & & $0.029^{*}$ & & $0.063^{* *}$ \\
\hline & & & $(0.02)$ & & $(0.03)$ \\
\hline \multirow[t]{2}{*}{ Paym/y * FL (4/4) } & & & -0.070 & & \\
\hline & & & $(0.04)$ & & \\
\hline \multirow[t]{2}{*}{ Paym/y * FL (N/4) } & & & & & $-0.019^{*}$ \\
\hline & & & & & $(0.01)$ \\
\hline $\mathrm{N}$ & 589 & 589 & 589 & 589 & 589 \\
\hline
\end{tabular}

Notes: ${ }^{*} p<0.1,{ }^{* *} p<0.05,{ }^{* * *} p<0.01$. Explanatory variables include a full set of dummies for the year when the mortgage was taken out. The table reports marginal effects. Standard errors robust to heteroskedasticity are in brackets. Monetary variables are in 2008 thousand euro. 
Our papers can be downloaded at:

http://cerp.unito.it/index.php/en/publications

\section{CeRP Working Paper Series}

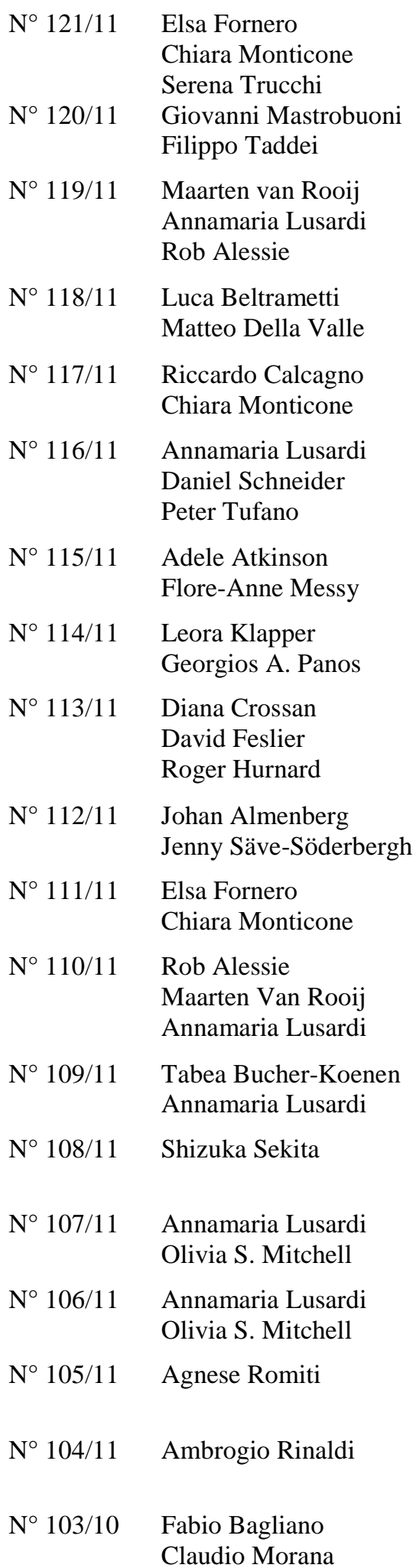

The effect of financial literacy on mortgage choices

Age Before Beauty? Productivity and Work vs. Seniority and Early Retirement

Financial Literacy, Retirement Planning, and Household Wealth

Does the implicit pension debt mean anything after all?

Financial Literacy and the Demand for Financial Advice

Financially Fragile Households: Evidence and Implications

Assessing financial literacy in 12 countries: an OECD Pilot Exercise

Financial Literacy and Retirement Planning in View of a Growing Youth Demographic: The Russian Case

Financial Literacy and Retirement Planning in New Zealand

Financial Literacy and Retirement Planning in Sweden

Financial Literacy and Pension Plan Participation in Italy

Financial Literacy, Retirement Preparation and Pension Expectations in the Netherlands

Financial Literacy and Retirement Planning in Germany

Financial Literacy and Retirement Planning in Japan

Financial Literacy and Retirement Planning in the United States

Financial Literacy Around the World: An Overview

Immigrants-natives complementarities in production: evidence from Italy

Pension awareness and nation-wide auto-enrolment: the Italian experience

The Great Recession: US dynamics and spillovers to the world economy 


\begin{tabular}{|c|c|}
\hline $\mathrm{N}^{\circ} 102 / 10$ & $\begin{array}{l}\text { Nuno Cassola } \\
\text { Claudio Morana }\end{array}$ \\
\hline $\mathrm{N}^{\circ} 101 / 10$ & Tetyana Dubovyk \\
\hline $\mathrm{N}^{\circ} 100 / 10$ & $\begin{array}{l}\text { Laura Piatti } \\
\text { Giuseppe Rocco }\end{array}$ \\
\hline $\mathrm{N}^{\circ} 99 / 10$ & $\begin{array}{l}\text { Fabio Bagliano } \\
\text { Claudio Morana }\end{array}$ \\
\hline $\mathrm{N}^{\circ} 98 / 10$ & $\begin{array}{l}\text { Annamaria Lusardi } \\
\text { Daniel Schneider } \\
\text { Peter Tufano }\end{array}$ \\
\hline $\mathrm{N}^{\circ} 97 / 10$ & $\begin{array}{l}\text { Carlo Maccheroni } \\
\text { Tiziana Barugola }\end{array}$ \\
\hline $\mathrm{N}^{\circ} 96 / 10$ & $\begin{array}{l}\text { Riccardo Calcagno } \\
\text { Mariacristina Rossi }\end{array}$ \\
\hline $\mathrm{N}^{\circ} 95 / 10$ & $\begin{array}{l}\text { Flavia Coda Moscarola } \\
\text { Elsa Fornero } \\
\text { Mariacristina Rossi }\end{array}$ \\
\hline $\mathrm{N}^{\circ} 94 / 10$ & $\begin{array}{l}\text { John A. List } \\
\text { Sally Sadoff } \\
\text { Mathis Wagner }\end{array}$ \\
\hline $\mathrm{N}^{\circ} 93 / 10$ & Mathis Wagner \\
\hline $\mathrm{N}^{\circ} 92 / 10$ & $\begin{array}{l}\text { Rob Alessie } \\
\text { Michele Belloni }\end{array}$ \\
\hline $\mathrm{N}^{\circ} 91 / 09$ & $\begin{array}{l}\text { Annamaria Lusardi } \\
\text { Olivia S. Mitchell } \\
\text { Vilsa Curto }\end{array}$ \\
\hline $\mathrm{N}^{\circ} 90 / 09$ & $\begin{array}{l}\text { Annamaria Lusardi } \\
\text { Olivia S. Mitchell }\end{array}$ \\
\hline$N^{\circ} 89 / 09$ & Elena Vigna \\
\hline
\end{tabular}

$\begin{array}{ll}\mathrm{N}^{\circ} 88 / 09 & \text { Maela Giofré } \\ \mathrm{N}^{\circ} 87 / 09 & \begin{array}{l}\text { Elsa Fornero } \\ \text { Annamaria Lusardi } \\ \text { Chiara Monticone }\end{array} \\ & \begin{array}{l}\text { Margherita Borella } \\ \text { Fo 86via Coda Moscarola }\end{array} \\ & \text { Cathal O’Donoghue } \\ \mathrm{N}^{\circ} 85 / 09 & \begin{array}{l}\text { John Lennon } \\ \text { Stephen Hynes }\end{array} \\ \mathrm{N}^{\circ} 84 / 09 & \text { Luca Spataro } \\ & \\ \mathrm{N}^{\circ} 83 / 09 & \begin{array}{l}\text { Annamaria Lusardi } \\ \text { Peter Tufano }\end{array} \\ & \text { Carolina Fugazza } \\ \mathrm{N}^{\circ} 82 / 09 & \text { Massimo Guidolin }\end{array}$

The 2007-? financial crisis: a money market perspective

Macroeconomic Aspects of Italian Pension Reforms of 1990s

L'educazione e la comunicazione previdenziale - Il caso italiano

The effects of US economic and financial crises on euro area convergence

The Economic Crisis and Medical Care Usage

E se l'aspettativa di vita continuasse la sua crescita? Alcune ipotesi per le generazioni italiane 1950-2005

Portfolio Choice and Precautionary Savings

Parents/children "deals": Inter-Vivos Transfers and Living Proximity

So you want to run an experiment, now what? Some Simple Rules of Thumb for Optimal Experimental Design

The Heterogeneous Labor Market Effects of Immigration

Retirement choices in Italy: what an option value model tells us

Financial Literacy among the Young:

Evidence and Implications for Consumer Policy

How Ordinary Consumers Make Complex Economic Decisions: Financial Literacy and Retirement Readiness

Mean-variance inefficiency of CRRA and CARA utility functions for portfolio selection in defined contribution pension schemes

Convergence of EMU Equity Portfolios

Adequacy of Saving for Old Age in Europe

Microsimulation of Pension Reforms: Behavioural versus Nonbehavioural Approach

The Life-Cycle Income Analysis Model (LIAM): A Study of a Flexible Dynamic Microsimulation Modelling Computing Framework

Il sistema previdenziale italiano dallo shock petrolifero del 1973 al Trattato di Maastricht del 1993

Debt Literacy, Financial Experiences, and Overindebtedness

Time and Risk Diversification in Real Estate Investments: Assessing the Ex Post Economic Value 
Giovanna Nicodano

\begin{tabular}{|c|c|}
\hline $\mathrm{N}^{\circ} 81 / 09$ & $\begin{array}{l}\text { Fabio Bagliano } \\
\text { Claudio Morana }\end{array}$ \\
\hline$N^{\circ} 80 / 08$ & Claudio Campanale \\
\hline $\mathrm{N}^{\circ} 79 / 08$ & Annamaria Lusardi \\
\hline $\mathrm{N}^{\circ} 78 / 08$ & $\begin{array}{l}\text { Margherita Borella } \\
\text { Giovanna Segre }\end{array}$ \\
\hline $\mathrm{N}^{\circ} 77 / 08$ & $\begin{array}{l}\text { Giovanni Guazzarotti } \\
\text { Pietro Tommasino }\end{array}$ \\
\hline $\mathrm{N}^{\circ} 76 / 08$ & $\begin{array}{l}\text { Riccardo Calcagno } \\
\text { Elsa Fornero } \\
\text { Mariacristina Rossi }\end{array}$ \\
\hline $\mathrm{N}^{\circ} 75 / 08$ & $\begin{array}{l}\text { Harold Alderman } \\
\text { Johannes Hoogeveen } \\
\text { Mariacristina Rossi }\end{array}$ \\
\hline $\mathrm{N}^{\circ} 74 / 08$ & Maela Giofré \\
\hline $\mathrm{N}^{\circ} 73 / 08$ & $\begin{array}{l}\text { Michele Belloni } \\
\text { Rob Alessie }\end{array}$ \\
\hline $\mathrm{N}^{\circ} 72 / 08$ & $\begin{array}{l}\text { Annamaria Lusardi } \\
\text { Olivia Mitchell }\end{array}$ \\
\hline
\end{tabular}

N ${ }^{\circ} 70 / 07 \quad$ Radha Iyengar Giovanni Mastrobuoni

$\begin{array}{ll}\text { N}^{\circ} 69 / 07 & \begin{array}{l}\text { Carolina Fugazza } \\ \text { Massimo Guidolin } \\ \text { Giovanna Nicodano }\end{array} \\ \text { N}^{\circ} \text { 68/07 } & \begin{array}{l}\text { Massimo Guidolin } \\ \text { Giovanna Nicodano }\end{array} \\ & \text { Carolina Fugazza } \\ \text { No 67/07 } & \begin{array}{l}\text { Maela Giofré } \\ \text { Giovanna Nicodano }\end{array} \\ & \text { Maarten van Rooij } \\ \text { No 66/07 } & \text { Rob Alessie } \\ & \text { Annamaria Lusardi }\end{array}$

$\mathrm{N}^{\circ}$ 65/07 Annamaria Lusardi

$\mathrm{N}^{\circ}$ 64/07 Carlo Casarosa

Luca Spataro
Permanent and Transitory Dynamics in House Prices and Consumption: Cross-Country Evidence

Learning, Ambiguity and Life-Cycle Portfolio Allocation

Increasing the Effectiveness of Financial Education in the Workplace

Le pensioni dei lavoratori parasubordinati: prospettive dopo un decennio di gestione separata

The Annuity Market in an Evolving Pension System: Lessons from Italy

The Effect of House Prices on Household Saving: The Case of Italy

Preschool Nutrition and Subsequent Schooling Attainment: Longitudinal Evidence from Tanzania

Information Asymmetries and Foreign Equity Portfolios: Households versus Financial Investors

The Importance of Financial Incentives on Retirement Choices: New Evidence for Italy

Planning and Financial Literacy: How Do Women Fare?

Women participation and caring decisions: do different institutional frameworks matter? A comparison between Italy and The Netherlands

The Political Economy of the Disability Insurance. Theory and Evidence of Gubernatorial Learning from Social Security Administration Monitoring

Investing in Mixed Asset Portfolios: the Ex-Post Performance

Small Caps in International Diversified Portfolios

International Diversification and Labor Income Risk

Financial Literacy and Stock Market Participation

Household Saving Behavior: The Role of Literacy, Information and Financial Education Programs

(Updated version June 08: "Financial Literacy: An Essential Tool for Informed Consumer Choice?")

Rate of Growth of Population, Saving and Wealth in the Basic Life-cycle Model when the Household is the Decision Unit 
Margherita Borella

Elsa Fornero

Mariacristina Rossi

$N^{\circ} 61 / 07 \quad$ Irina Kovrova

$\begin{array}{ll}N^{\circ} 60 / 07 & \text { Riccardo Cesari } \\ & \text { Giuseppe Grande } \\ & \text { Fabio Panetta }\end{array}$

N ${ }^{\circ} 59 / 07 \quad$ Riccardo Calcagno

Roman Kraeussl

Chiara Monticone

$N^{\circ} 58 / 07 \quad$ Elisa Luciano

Jaap Spreeuw

Elena Vigna

$N^{\circ} 57 / 07 \quad$ Giovanni Mastrobuon Matthew Weinberg

$\mathrm{N}^{\circ} 56 / 07 \quad$ John A. Turner

Satyendra Verma

$\mathrm{N}^{\circ} 55 / 06 \quad$ Antonio Abatemarco

N ${ }^{\circ}$ 54/06 Annamaria Lusardi

Olivia S. Mitchell

$N^{\circ} 53 / 06 \quad$ Giovanni Mastrobuoni

$\mathrm{N}^{\circ}$ 52/06 Luigi Guiso

Tullio Jappelli

N $N^{\circ} 51 / 06 \quad$ Giovanni Mastrobuoni

N ${ }^{\circ} 50 / 06 \quad$ Andrea Buffa

Chiara Monticone

N ${ }^{\circ} 49 / 06 \quad$ Mariacristina Rossi

$\mathrm{N}^{\circ} 48 / 06 \quad$ Onorato Castellino Elsa Fornero

N ${ }^{\circ} 47 / 06 \quad$ Michele Belloni Carlo Maccheroni

$\mathrm{N}^{\circ} 46 / 05 \quad$ Annamaria Lusardi Olivia S. Mitchell

$N^{\circ} 45 / 05 \quad$ Claudio Campanale

$\mathrm{N}^{\circ} 44 / 05 \quad$ Henrik Cronqvist

$N^{\circ} 43 / 05 \quad$ John Beshears

James J. Choi

David Laibson

Brigitte C. Madrian

$N^{\circ} 42 / 05 \quad$ Margherita Borella

Flavia Coda Moscarola
Life-Cycle Portfolio Choice: The Role of Heterogeneous UnderDiversification

Does Consumption Respond to Predicted Increases in Cash-onhand Availability? Evidence from the Italian "Severance Pay"

Effects of the Introduction of a Funded Pillar on the Russian Household Savings: Evidence from the 2002 Pension Reform

La Previdenza Complementare in Italia:

Caratteristiche, Sviluppo e Opportunità per i Lavoratori

An Analysis of the Effects of the Severance Pay Reform on Credit to Italian SMEs

Modelling Stochastic Mortality for Dependent Lives

Heterogeneity in Intra-Monthly Consumption. Patterns, SelfControl, and Savings at Retirement

Why Some Workers Don't Take 401(k) Plan Offers: Inertia versus Economics

On the Measurement of Intra-Generational Lifetime Redistribution in Pension Systems

Baby Boomer Retirement Security: The Roles of Planning, Financial Literacy, and Housing Wealth

Labor Supply Effects of the Recent Social Security Benefit Cuts: Empirical Estimates Using Cohort Discontinuities

Information Acquisition and Portfolio Performance

The Social Security Earnings Test Removal. Money Saved or Money Spent by the Trust Fund?

Do European Pension Reforms Improve the Adequacy of Saving?

Examining the Interaction between Saving and Contributions to Personal Pension Plans. Evidence from the BHPS

Public Policy and the Transition to Private Pension Provision in the United States and Europe

Actuarial Neutrality when Longevity Increases: An Application to the Italian Pension System

Financial Literacy and Planning: Implications for Retirement Wellbeing

Increasing Returns to Savings and Wealth Inequality

Advertising and Portfolio Choice

The Importance of Default Options for Retirement Saving Outcomes: Evidence from the United States

Distributive Properties of Pensions Systems: a Simulation of the Italian Transition from Defined Benefit to Defined Contribution 


\begin{tabular}{|c|c|c|}
\hline $\mathrm{N}^{\circ} 41 / 05$ & $\begin{array}{l}\text { Massimo Guidolin } \\
\text { Giovanna Nicodano }\end{array}$ & $\begin{array}{l}\text { Small Caps in International Equity Portfolios: The Effects of } \\
\text { Variance Risk. }\end{array}$ \\
\hline $\mathrm{N}^{\circ} 40 / 05$ & $\begin{array}{l}\text { Carolina Fugazza } \\
\text { Massimo Guidolin } \\
\text { Giovanna Nicodano }\end{array}$ & $\begin{array}{l}\text { Investing for the Long-Run in European Real Estate. Does } \\
\text { Predictability Matter? }\end{array}$ \\
\hline $\mathrm{N}^{\circ} 39 / 05$ & Anna Rita Bacinello & $\begin{array}{l}\text { Modelling the Surrender Conditions in Equity-Linked Life } \\
\text { Insurance }\end{array}$ \\
\hline $\mathrm{N}^{\circ} 38 / 05$ & $\begin{array}{l}\text { Carolina Fugazza } \\
\text { Federica Teppa }\end{array}$ & $\begin{array}{l}\text { An Empirical Assessment of the Italian Severance Payment } \\
\text { (TFR) }\end{array}$ \\
\hline$N^{\circ} 37 / 04$ & Jay Ginn & $\begin{array}{l}\text { Actuarial Fairness or Social Justice? } \\
\text { A Gender Perspective on Redistribution in Pension Systems }\end{array}$ \\
\hline$N^{\circ} 36 / 04$ & Laurence J. Kotlikoff & $\begin{array}{l}\text { Pensions Systems and the Intergenerational Distribution of } \\
\text { Resources }\end{array}$ \\
\hline $\mathrm{N}^{\circ} 35 / 04$ & $\begin{array}{l}\text { Monika Bütler } \\
\text { Olivia Huguenin } \\
\text { Federica Teppa }\end{array}$ & $\begin{array}{l}\text { What Triggers Early Retirement. Results from Swiss Pension } \\
\text { Funds }\end{array}$ \\
\hline$N^{\circ} 34 / 04$ & Chourouk Houssi & $\begin{array}{l}\text { Le Vieillissement Démographique : } \\
\text { Problématique des Régimes de Pension en Tunisie }\end{array}$ \\
\hline $\mathrm{N}^{\circ} 33 / 04$ & $\begin{array}{l}\text { Elsa Fornero } \\
\text { Carolina Fugazza } \\
\text { Giacomo Ponzetto }\end{array}$ & $\begin{array}{l}\text { A Comparative Analysis of the Costs of Italian Individual } \\
\text { Pension Plans }\end{array}$ \\
\hline $\mathrm{N}^{\circ} 32 / 04$ & $\begin{array}{l}\text { Angelo Marano } \\
\text { Paolo Sestito }\end{array}$ & $\begin{array}{l}\text { Older Workers and Pensioners: the Challenge of Ageing on the } \\
\text { Italian Public Pension System and Labour Market }\end{array}$ \\
\hline $\mathrm{N}^{\circ} 31 / 03$ & Giacomo Ponzetto & Risk Aversion and the Utility of Annuities \\
\hline $\mathrm{N}^{\circ} 30 / 03$ & $\begin{array}{l}\text { Bas Arts } \\
\text { Elena Vigna }\end{array}$ & A Switch Criterion for Defined Contribution Pension Schemes \\
\hline $\mathrm{N}^{\circ} 29 / 02$ & Marco Taboga & $\begin{array}{l}\text { The Realized Equity Premium has been Higher than Expected: } \\
\text { Further Evidence }\end{array}$ \\
\hline $\mathrm{N}^{\circ} 28 / 02$ & Luca Spataro & $\begin{array}{l}\text { New Tools in Micromodeling Retirement Decisions: Overview } \\
\text { and Applications to the Italian Case }\end{array}$ \\
\hline $\mathrm{N}^{\circ} 27 / 02$ & Reinhold Schnabel & $\begin{array}{l}\text { Annuities in Germany before and after the Pension Reform of } \\
2001\end{array}$ \\
\hline$N^{\circ} 26 / 02$ & E. Philip Davis & Issues in the Regulation of Annuities Markets \\
\hline $\mathrm{N}^{\circ} 25 / 02$ & $\begin{array}{l}\text { Edmund Cannon } \\
\text { Ian Tonks }\end{array}$ & The Behaviour of UK Annuity Prices from 1972 to the Present \\
\hline $\mathrm{N}^{\circ} 24 / 02$ & $\begin{array}{l}\text { Laura Ballotta } \\
\text { Steven Haberman }\end{array}$ & Valuation of Guaranteed Annuity Conversion Options \\
\hline $\mathrm{N}^{\circ} 23 / 02$ & Ermanno Pitacco & Longevity Risk in Living Benefits \\
\hline $\mathrm{N}^{\circ} 22 / 02$ & $\begin{array}{l}\text { Chris Soares } \\
\text { Mark Warshawsky }\end{array}$ & $\begin{array}{l}\text { Annuity Risk: Volatility and Inflation Exposure in Payments } \\
\text { from Immediate Life Annuities }\end{array}$ \\
\hline $\mathrm{N}^{\circ} 21 / 02$ & $\begin{array}{l}\text { Olivia S. Mitchell } \\
\text { David McCarthy }\end{array}$ & Annuities for an Ageing World \\
\hline$N^{\circ} 20 / 02$ & Mauro Mastrogiacomo & Dual Retirement in Italy and Expectations \\
\hline
\end{tabular}




\begin{tabular}{|c|c|c|}
\hline $\mathrm{N}^{\circ} 19 / 02$ & $\begin{array}{l}\text { Paolo Battocchio } \\
\text { Francesco Menoncin }\end{array}$ & $\begin{array}{l}\text { Optimal Portfolio Strategies with Stochastic Wage Income and } \\
\text { Inflation: The Case of a Defined Contribution Pension Plan }\end{array}$ \\
\hline $\mathrm{N}^{\circ} 18 / 02$ & Francesco Daveri & $\begin{array}{l}\text { Labor Taxes and Unemployment: a Survey of the Aggregate } \\
\text { Evidence }\end{array}$ \\
\hline $\mathrm{N}^{\circ} 17 / 02$ & $\begin{array}{l}\text { Richard Disney and } \\
\text { Sarah Smith }\end{array}$ & $\begin{array}{l}\text { The Labour Supply Effect of the Abolition of the Earnings Rule } \\
\text { for Older Workers in the United Kingdom }\end{array}$ \\
\hline $\mathrm{N}^{\circ} 16 / 01$ & $\begin{array}{l}\text { Estelle James and } \\
\text { Xue Song }\end{array}$ & $\begin{array}{l}\text { Annuities Markets Around the World: Money's Worth and Risk } \\
\text { Intermediation }\end{array}$ \\
\hline$N^{\circ} 15 / 01$ & Estelle James & $\begin{array}{l}\text { How Can China Solve ist Old Age Security Problem? The } \\
\text { Interaction Between Pension, SOE and Financial Market Reform }\end{array}$ \\
\hline$N^{\circ} 14 / 01$ & Thomas H. Noe & Investor Activism and Financial Market Structure \\
\hline $\mathrm{N}^{\circ} 13 / 01$ & Michela Scatigna & Institutional Investors, Corporate Governance and Pension Funds \\
\hline $\mathrm{N}^{\circ} 12 / 01$ & Roberta Romano & $\begin{array}{l}\text { Less is More: Making Shareholder Activism a Valuable } \\
\text { Mechanism of Corporate Governance }\end{array}$ \\
\hline $\mathrm{N}^{\circ} 11 / 01$ & $\begin{array}{l}\text { Mara Faccio and Ameziane } \\
\text { Lasfer }\end{array}$ & $\begin{array}{l}\text { Institutional Shareholders and Corporate Governance: The Case } \\
\text { of UK Pension Funds }\end{array}$ \\
\hline $\mathrm{N}^{\circ} 10 / 01$ & $\begin{array}{l}\text { Vincenzo Andrietti and Vincent } \\
\text { Hildebrand }\end{array}$ & $\begin{array}{l}\text { Pension Portability and Labour Mobility in the United States. } \\
\text { New Evidence from the SIPP Data }\end{array}$ \\
\hline$N^{\circ} 9 / 01$ & Hans Blommestein & $\begin{array}{l}\text { Ageing, Pension Reform, and Financial Market Implications in } \\
\text { the OECD Area }\end{array}$ \\
\hline $\mathrm{N}^{\circ} 8 / 01$ & Margherita Borella & $\begin{array}{l}\text { Social Security Systems and the Distribution of Income: an } \\
\text { Application to the Italian Case }\end{array}$ \\
\hline $\mathrm{N}^{\circ} 7 / 01$ & Margherita Borella & $\begin{array}{l}\text { The Error Structure of Earnings: an Analysis on Italian } \\
\text { Longitudinal Data }\end{array}$ \\
\hline$N^{\circ} 6 / 01$ & Flavia Coda Moscarola & $\begin{array}{l}\text { The Effects of Immigration Inflows on the Sustainability of the } \\
\text { Italian Welfare State }\end{array}$ \\
\hline $\mathrm{N}^{\circ} 5 / 01$ & Vincenzo Andrietti & $\begin{array}{l}\text { Occupational Pensions and Interfirm Job Mobility in the } \\
\text { European Union. Evidence from the ECHP Survey }\end{array}$ \\
\hline $\mathrm{N}^{\circ} 4 / 01$ & Peter Diamond & Towards an Optimal Social Security Design \\
\hline $\mathrm{N}^{\circ} 3 / 00$ & $\begin{array}{l}\text { Emanuele Baldacci } \\
\text { Luca Inglese }\end{array}$ & $\begin{array}{l}\text { Le caratteristiche socio economiche dei pensionati in Italia. } \\
\text { Analisi della distribuzione dei redditi da pensione (only available } \\
\text { in the Italian version) }\end{array}$ \\
\hline $\mathrm{N}^{\circ} 2 / 00$ & $\begin{array}{l}\text { Pier Marco Ferraresi } \\
\text { Elsa Fornero }\end{array}$ & $\begin{array}{l}\text { Social Security Transition in Italy: Costs, Distorsions and (some) } \\
\text { Possible Correction }\end{array}$ \\
\hline $\mathrm{N}^{\circ} 1 / 00$ & Guido Menzio & Opting Out of Social Security over the Life Cycle \\
\hline
\end{tabular}

